\title{
Chemical compositions of the late Cretaceous granitoids across the central part of the Abukuma Highland, Japan - Revisited
}

\author{
Shunso Ishihara ${ }^{1}$ and Bruce W. Chappell ${ }^{2}$
}

\begin{abstract}
Shunso Ishihara and Bruce W. Chappell(2008) Chemical compositions of the late Cretaceous granitoids across the central part of the Abukuma Highland, Japan - Revisited. Bull. Geol. Surv. Japan, vol. 59 (3/4), p. 151-170, 10 figs, 1 appendixs.
\end{abstract}

\begin{abstract}
Late Cretaceous granitoids of central area in the Abukuma terrain were analyzed by polarized XRF method and compared with the Ryoke granitoids of Chubu district. The Abukuma granitoids are mostly composed of hornblende and/or biotite granodiorite to granite and less in amount of muscovite-biotite granites, and are higher in $\mathrm{Na}_{2} \mathrm{O}$ and $\mathrm{Al}_{2} \mathrm{O}_{3}$, lower in $\mathrm{K}_{2} \mathrm{O}, \mathrm{Rb}, \mathrm{Pb}$ and $\mathrm{Ba}$ than the Ryoke granitoids on the Harker diagrams. The Abukuma granitoids appear to be generated within the continental crust of inmatured island-arcs, having mafic magmas and heat from the upper mantle.

The Abukuma granitoids are generally reduced type accepting sedimentary carbon from the continental crust, similarly to the Ryoke granitoids, but an intermediate series occurs in the eastern-end zone. Zone II granitoids, which are rich in $\mathrm{CaO}$ and poor in $\mathrm{K}_{2} \mathrm{O}$ and lithophile components such as $\mathrm{Rb}, \mathrm{Pb}, \mathrm{Y}, \mathrm{Ce}$ and La, have weak signature of high $\mathrm{Sr} / \mathrm{Y}$ ratio for adakite. An adakitic magma may have brought up from the subducting slab, but extremely modified within the continental crust.
\end{abstract}

Keywords: Abukuma, Late Cretaceous, granitoids, ilmenite series, intermediate series, I type, S type, major elements, minor elements.

\section{Introduction}

The Abukuma Highland is underlain by metamorphic and plutonic rocks. The metamorphism is considered similar to that of the Ryoke metamorphic belt, both belonging to the andalusite-sillimanite type, but the original rocks are different being mafic and low $\mathrm{K}_{2} \mathrm{O} /\left(\mathrm{K}_{2} \mathrm{O}+\mathrm{Na}_{2} \mathrm{O}\right)$ rocks predominant in the Abukuma Belt (Miyashiro, 1958; Miyashiro, 1965). Regional distribution of the metamorphic grades increases westward toward the Tanakura Tectonic Line in the Abukuma Highland, similarly to the increasing of the grade toward the Median Tectonic Line in the Ryoke Belt of Southwest Japan. Thus, these major faults have important bearing on the heat source for the metamorphism.

Reconnaissance chemical studies using gamma-ray spectrometry for $\mathrm{K}_{2} \mathrm{O}$, Th and $\mathrm{U}$, were made on granitic and metamorphic rocks of the central transect around $\mathrm{N} 34^{\circ} \mathrm{N}$ of the Abukuma Highland in the 1960s under "Uranium Project" of the Geological Survey of Japan (Ishihara et al, 1973). Uranium and thorium of these granitoids are low in the western part, while relatively high in the eastern part where bedded-type uranium deposits occur in the overlying Miocene sediments. The same powders of two gabbroids and fifty-six granitoids (Ishihara et al., 1973) are here re-analyzed by the polarized XRF technique for both major and minor elements by Bruce W. Chappell at the Macquarie University. Seven samples were added from the underground workings of the Yaguki scheelite-skarn deposits.

The analytical results are listed in the appendix. The whole results are classified regionally from west to east, and the regional variation is examined. The results are also compared with the chemical compositions of the Ryoke granitoids of the Chubu District (Ishihara and Chappell, 2007), which have been analyzed by the same methods and analyst. The Ryoke granitoids of the Chubu and Kanto districts have high initial ${ }^{87} \mathrm{Sr} / \mathrm{Sr}^{86}$ ratios of 0.7076-0.7124 (except for the Kamihara tonalite) but the Abukuma granitoids have lower values of $0.7047-0.7055$ (Shibata and Ishihara, 1979).

\section{Geological Outline}

Abukuma Highland of Fukushima Prefecture is underlain by sedimentary and metamorphic rocks of Jurassic age, which was identified by micro-fossils in the intercalated cherts (Hiroi et al., 1987). The metamorphic rocks are divided into the western Takanuki type and the eastern

${ }^{1}$ National Institute of Advanced Industrial Science and Technology (AIST), Central 7, AIST, Tsukuba, Japan

${ }^{2}$ School of Earth \& Environmental Sciences, University of Wollongong, NSW 2522, Australia 


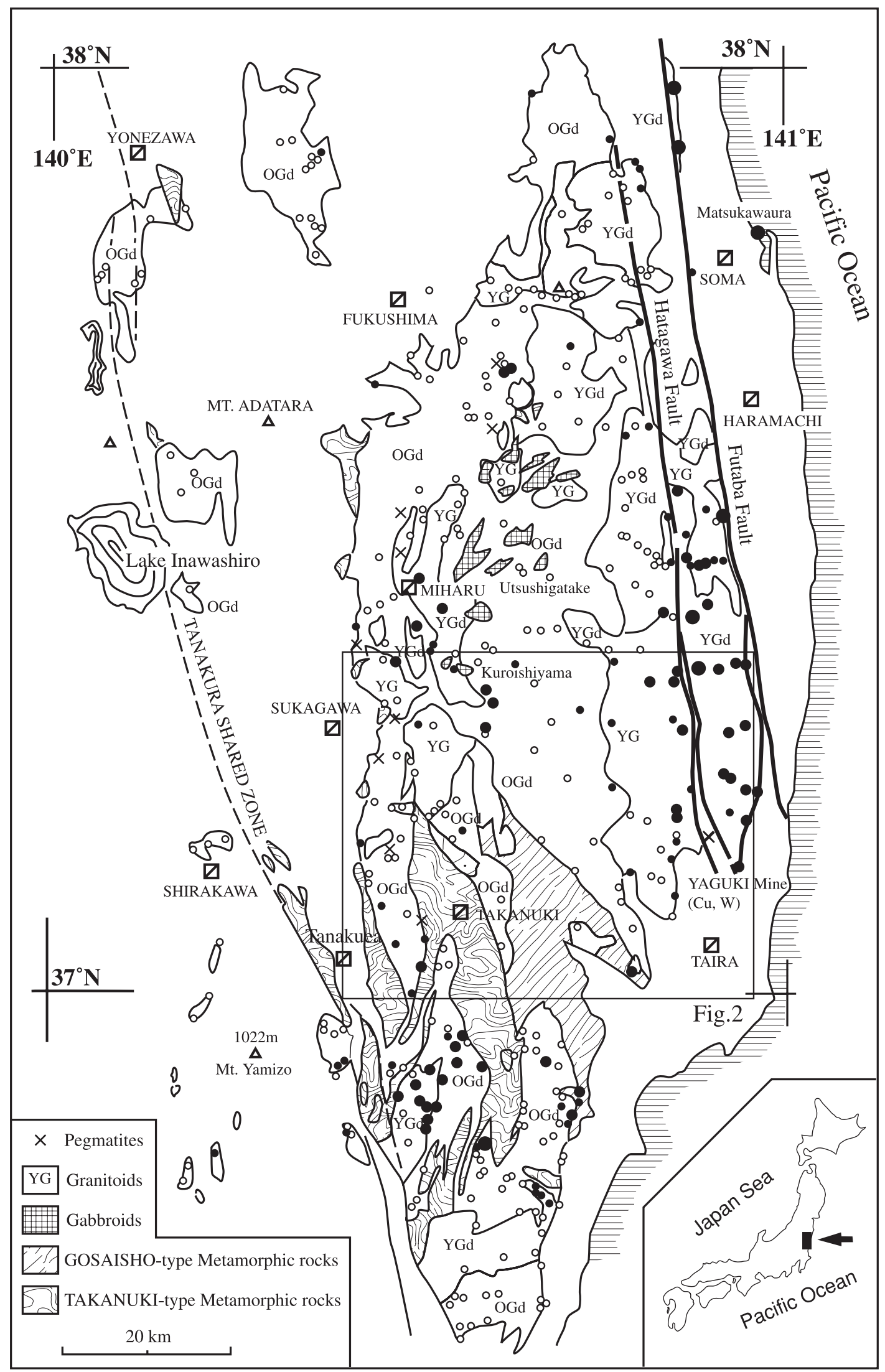

Fig. 1 Regional distribution of magnetic susceptibility of the Cretaceous granitoids in the Abukuma Belt (modified from Ishihara, 1990). $\circ$ : Magnetic susceptibility less than $29 \times 10^{-6} \mathrm{emu} / \mathrm{g}$ (i.e., ilmenite series), $\bullet$ : Intermediate series(small one, 30-99, medium one 100-299, large one higher than 300 x $10^{-6} \mathrm{emu} / \mathrm{g}$. OGd, Older granodiorite; YGd, Younger granodiorite; YG, Younger granite. 
Gosaisho type (Fig. 1). Intruding these rocks, Cretaceous plutonic rocks occur in N-S directions, which are mostly granitoids with a small amount of gabbroids contained in the granitoids as xenolithic bodies (Kubo, 1991).

The granitoids are divided originally into "older" and "younger" (Watanabe et al., 1955, see also Fig. 1). The older granitoids tend to have foliation regionally, which would have been caused by a regional stress effect. The foliation indeed prevails in the western part where the matemorphic grade is the highest across the Abukuma terrain and depth of the granitoid emplacement may be the largest, but among the older granitoids in the eastern part, the foliation is limited close to the N-S faults, implying different genetic background involved in genesis of the foliation (Ishihara et al., 1973).

Based upon field relationship and rock facies, the granitoids are subdivided into three major phases in the Fukushima sheet of 1:200,000 scale map (Kubo et al., 2003), as (i) foliated hornblende-biotite quartz diorite to granodiorite $\left(\mathrm{G}_{2 \mathrm{a}}\right)$ distributed in wide areas including the Ishikawa mass, (ii) hornblende-bearing biotite granodiorite to biotite granite $\left(\mathrm{G}_{2 \mathrm{~b}}\right)$ in the eastern and central parts, and (iii) muscovitebiotite granite $\left(\mathrm{G}_{2 \mathrm{c}}\right)$ intruded locally into the biotite granite and metamorphic rocks.
Age difference between the older and younger granitoids is unclear by the modern geochronological determination. A typical older granodiorite of the Ishikawa composite mass to the west of the studied region exhibits a $\mathrm{Rb}-\mathrm{Sr}$ isochron age of $106 \pm 16 \mathrm{Ma}$ with an initial ${ }^{87} \mathrm{Sr} /{ }^{86} \mathrm{Sr}$ ratio of $0.70518 \pm 15$ and a $\mathrm{Nd} / \mathrm{Sm}$ age of $111 \pm 42 \mathrm{Ma}$ with an initial ${ }^{145} \mathrm{Nd} /{ }^{144} \mathrm{Nd}$ of $0.51251 \pm 3$ (Shibata and Tanaka, 1987). $\mathrm{K}-\mathrm{Ar}$ ages of hornblende and biotite of the granitoids in the eastern Haramachi district (Fig. 1) vary from $126.6 \pm 6$ to 96 $\pm 5 \mathrm{Ma}$ (Kubo and Yamamoto, 1990). Thus, more precise age determinations (e.g. SHRIMP zircon age) are needed throughout the studied region.

\subsection{Five zones of the granitoids}

The studied granitoids are divided into Zones I to V from the west to east, then underground samples of the Yaguki mine (Fig. 2). Zone I granitoids occur mostly in the highest metamorphic grade C zone of Miyashiro (1958). They are mostly "older" hornblende-biotite granodiorite-quartz diorite (Ishikawa type) having silica contents of 57.7-67.3 $\%$, but small amount of felsic per-aluminous muscovitebiotite granite $(68 \mathrm{~A} 14,34,35)$ is present, similarly to the Busetsu Granite of the Ryoke Belt, where the muscovitebiotite granite tends to occur in the highest-grade, sillimanite

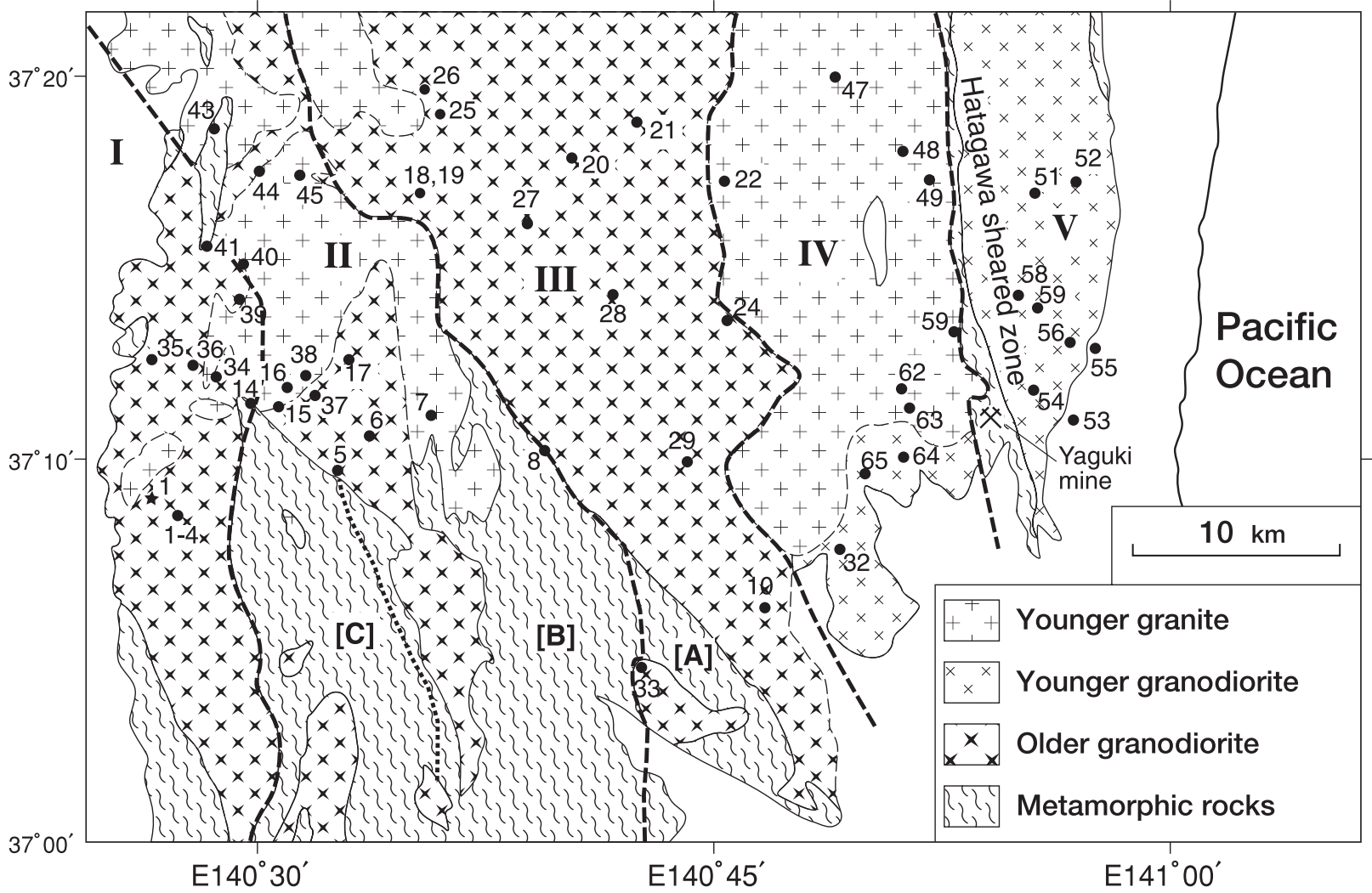

Fig. 2 Geologic map and sample localities of the studied granitoids. The geologic map from Ishihara and Matsuhisa (2004) 
zone of the regional metamorphism (Ishihara and Chappell, 2007). The samples from 68A01 to 04 are taken from single outcrop in the Ishikawa township, and reveal heterogeneity of the quartz diorite-granodiorite, having the silica range of 57.7 (68A01) and $68.4 \%$ (68A03), and even $74.3 \%$ (68A04), which is schlieren-like flat dikelet consisting of very finegrained biotite tonalite.

Zone II granitoids occur roughly in the $\mathrm{B}$ and $\mathrm{C}$ zones of the metamorphic belt (Fig. 2), and are composed of "older" granodiorite and "younger" granite, and have the silica range of $65.3-74.3 \%$. Zone III granitoids occur in the A and B zones of the metamorphic belt and consist of hornblendebiotite granodiorite and biotite granite, having silica range of $62.1-75.3 \%$. Zone IV granitoids occurring in none metamorphic zones (Fig. 2) are felsic, biotite granite, laving silica contents from 70.1 to $75.1 \%$, although the southernmost part was previously reported as granodiorite.

Zone V granitoids, occurring the Hatagawa Sheared Zone eastward in none-metamorphic zone, are mostly hornblendebiotite granodiorite with silica range of 65.9-69.6\%. These granitoids and also granodiorite of further east of Matsukawaura, (Fig. 1), which was discovered by drilling near the Pacific coast (Abe and Ishihara, 1985) belong to magnetite series. But the magnetic susceptibilities are much lower than those of the typical magnetite-series granitoids in Southwest Japan (Fig. 3).

\subsection{Granitoids of the Yaguki Mine}

The Yaguki mine was discovered and mined in 1394 by a local government of that area, but a modern mining was initiated in 1907 when the Yaguki mining company was established. The Nittetsu Mining Co. acquired the property in 1954 and operated by 1988 . The mine is essentially copper mine, and magnetite and scheelite were recovered in later years. The total productions during the Nittetsu Mining stage are as follows:

59,241 tons $\mathrm{Cu}$ from 275,717 tons of chalcopyrite concentrate $(21.49 \% \mathrm{Cu})$,

565,401 tons magnetite $(62.37 \% \mathrm{Fe})$, and

2,491 tons $\mathrm{WO}_{3}$ (1971-1988) from 2,952 tons of scheelite concentrates, including a small amount of Date-Nagai skarn ores, according to the Nittetsu Mining Co.

The mine is composed of scheelite-rich chalcopyritepyrrhotite-magnetite skarn deposits of No. 1 orebody, No. 2 orebody, No. 3 orebody, No.4 orebody, Asahi-ko orebody, Nanbu-Hiyama orebody, Akahage orebody and Tenpo orebody, and studied well by mineralogical and structural aspects (Shimazaki, 1969; Shoji et al., 1975; Muramatsu and Nanbu, 1975). In 1968, high-grade scheelite skarn

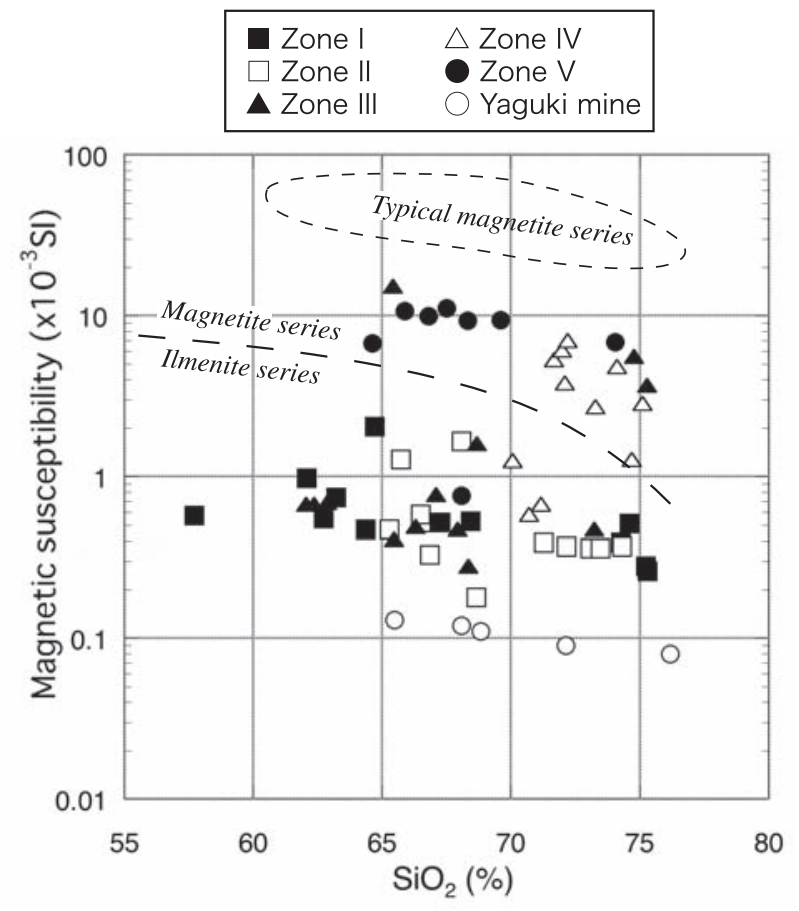

Fig. 3 Magnetic susceptibility vs. $\mathrm{SiO}_{2}$ contents of the studied granitoids. The magnetite and ilmenite-series boundary is taken from Ishihara (2002).

orebodies were discovered by exploration toward deeper part of No. 1 orebody where scheelite disseminates in lens shape in skarn and limestone (Ogawa and Shida, 1975). Skarn minerals of the Yaguki deposits are mostly Fe-rich andradite and hedenbergite with minor amounts of edpidote, diopside, wollastonite, babingtonite, quartz and calcite. The ore minerals are chalcopyrite, cubanite, sphalerite, magnetite, pyrite, pyrrhotite and scheelite. In the Tenpo deposit, the earlier scheelite contains 0.6 - $9 \mathrm{~mol} \% \mathrm{CaMoO}_{4}$, while the later scheelite is almost free $(<0.3 \mathrm{~mol} . \%)$ of the $\mathrm{CaMoO}_{4}$ component (Takahara and Nakano, 1993).

In the mine area, various rocks from ultramafics to sediments are exposed, direct host rocks for the W-Cu-Fe mineralizations are Permo-Carboniferous slate and limestone and Cretaceous granitoids (Ogawa and Shida, 1975), having a mineralization age on muscovite of $107 \pm 3 \mathrm{Ma}$ (Ishihara et al., 1988). The granitoids are stock in size intruding mainly along anticlinal axes of the sediments. They occur extensively in the underground workings, 5 to 30 meters below the skarn orebodies (Nittetsu Mining Co., 1965). They are free of magnetite, belonging to the ilmenite series. The composition varies from granodiorite to granite (65.9 76.2 $\% \mathrm{SiO}_{2}$, see appendix). Two low $\mathrm{SiO}_{2}$ rocks are skarnized ore $\left(0.5 \% \mathrm{~W}, 50.1 \% \mathrm{SiO}_{2}\right)$ and hydrothermally altered rock (53.4 $\% \mathrm{SiO}_{2}$ ). 


\section{Magnetic Susceptibility and Opaque Mineralogy}

Magnetically, metamorphic and plutonic complexes of the Abukuma Highland are quiet in the major, western and central parts, because the granitoids are mostly magnetite-free series (Fig. 3). Exceptionally, the Ishimori tonalite located just to the west of Utsushigatake gabbroids has been reported dominantly magnetite-bearing rocks (Kamei and Takagi, 2003). Large gabbroic bodies trapped in the granitoids are magnetic due to locally abundant contents of magnetite, but surrounding dioritic and more felsic rocks are often magnetite free. The metamorphic rocks have mostly magnetite-free values but are very locally magnetic due possibly to hematite in sedimentary Mn-Fe deposits (Yoshimura and Miyamoto, 1954), which have been converted to magnetite by the regional metamorphism.

Magnetic susceptibility of the Abukuma granitoids is generally below $99 \times 10^{-6} \mathrm{emu} / \mathrm{g}$, which is the upper limit of the ilmenite series. Intermediate to high values of $100-500$ $\times 10^{-6} \mathrm{emu} / \mathrm{g}$ (Fig. 3) are locally present in the southern and eastern parts (Fig. 1). The granitoids to the east of the Futaba Fault contain generally magnetite but belongs to intermediate series (Ishihara, 1990, also Fig. 3 in this paper). Gabbroic rocks have been trapped in the granitoids and quarried for

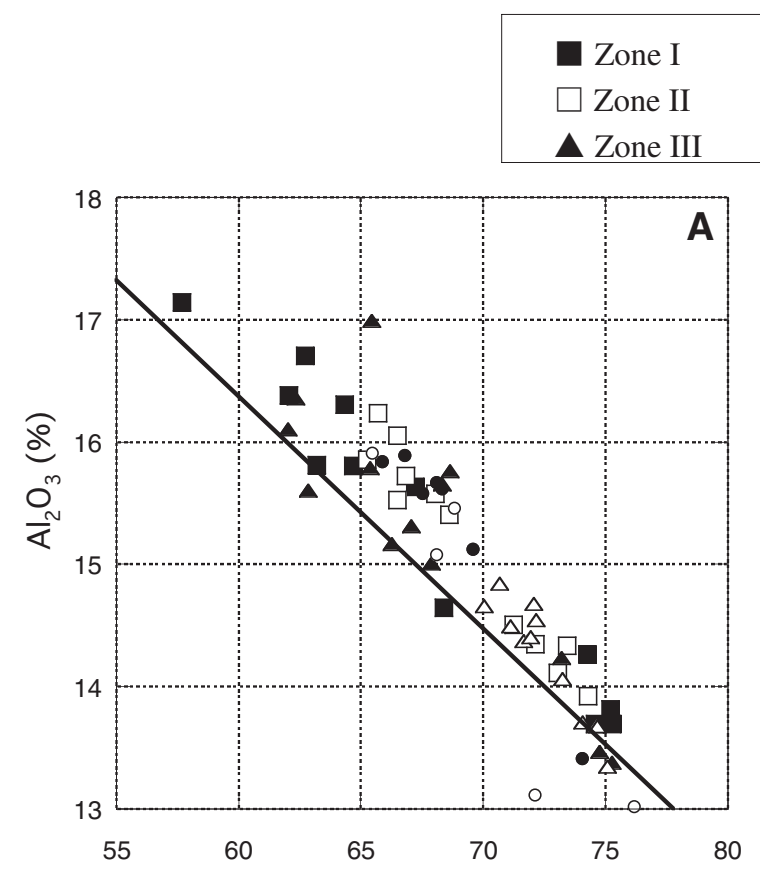

$\triangle$ Zone IV

- Zone V

$\bigcirc$ Yaguki mine
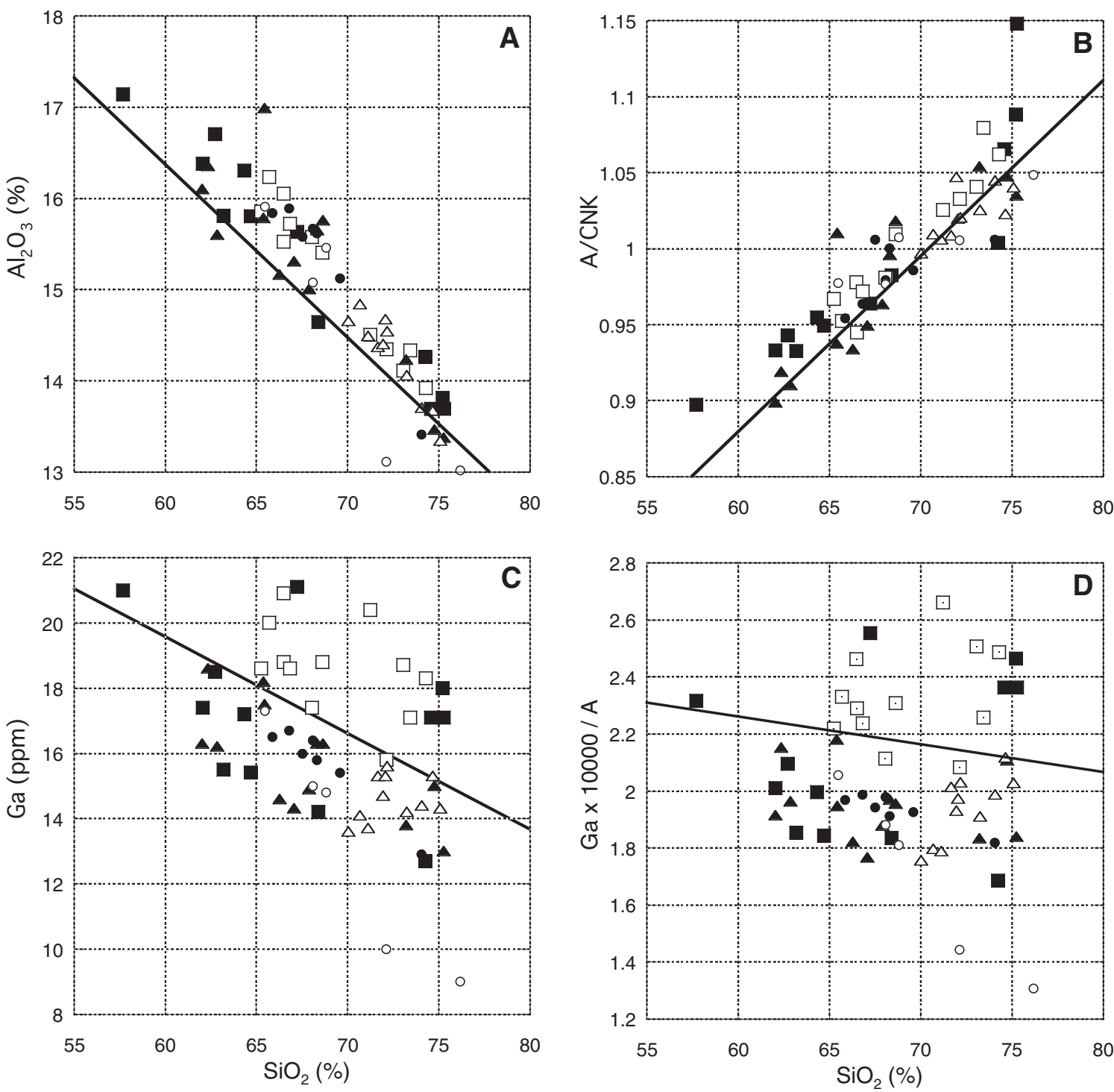

Fig. 4 Silica vs. $\mathrm{Al}_{2} \mathrm{O}_{3}, \mathrm{~A} / \mathrm{CNK}$. Ga and $\mathrm{Ga} \mathrm{x}$ 10000/A of the studied granitoids. Straight line is the regression line of the Ryoke granitoids (Ishihara and Chappell, 2007). 
various purposes (e.g., Utsushigatake and Kuroishiyama, Fig. 1). The most mafic phase of the gabbroids is strongly magnetic containing a rock-forming mineral of magnetite, which is coarse-grained polygonal to subhedral crystals closely associated with fine columnar crystals of ilmenite at margin. Both pyrrhotite and pyrite disseminate locally in the gabbroids or occur also in later veins.

The ilmenite-series granitoids contain very small amounts of ilmenite with columnar and/or granular shapes in and around mafic silicates. Titanite is also common. No hemoilmenite has been observed.

Magnetite-series granitoids of granodiorite composition to the east contain some amounts of polygonal to rounded magnetites in and around mafic silicates. Stubby crystals of ilmenite are generally abundant; titanite is fairly common. No hematitization is observed over the magnetite, implying a low degree of oxygen fugacity in a later magmatic stage. Intermediate-series biotite granite contains small amounts of magnetite in polygonal to rounded in shape, which occur with biotite and felsic minerals. One crystal of hematitized magnetite was observed on the high silica rock (68A48, 75.1 $\% \mathrm{SiO}_{2}$ ). The magnetite-bearing granitoids of the Abukuma terrain seem to be crystallized under lower oxygen fugacity than those of typical magnetite-series of the Sanin Belt.

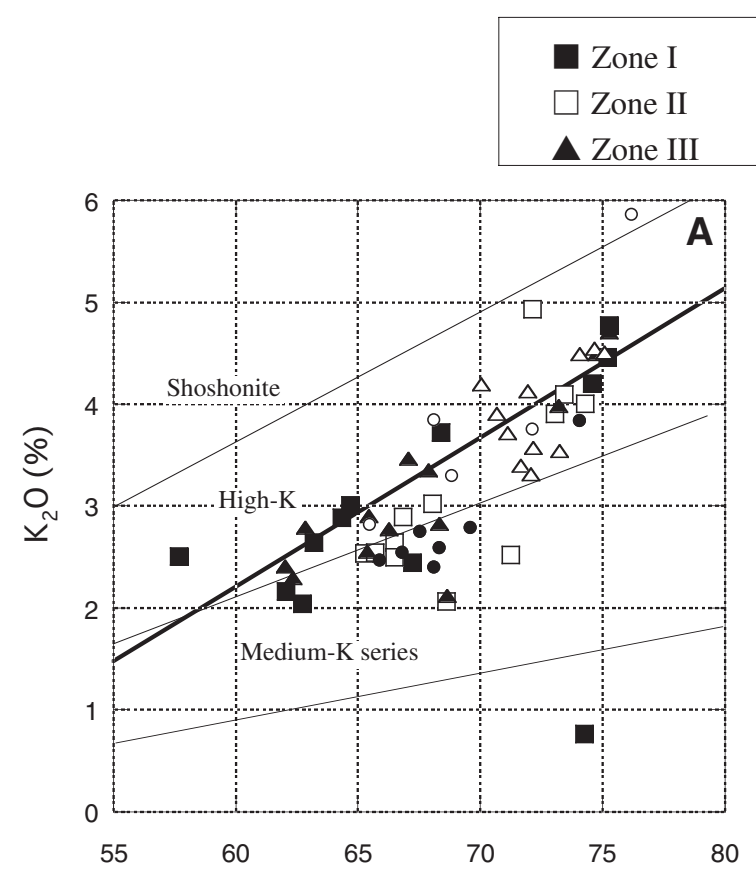

$\triangle$ Zone IV

- Zone V

$\bigcirc$ Yaguki mine
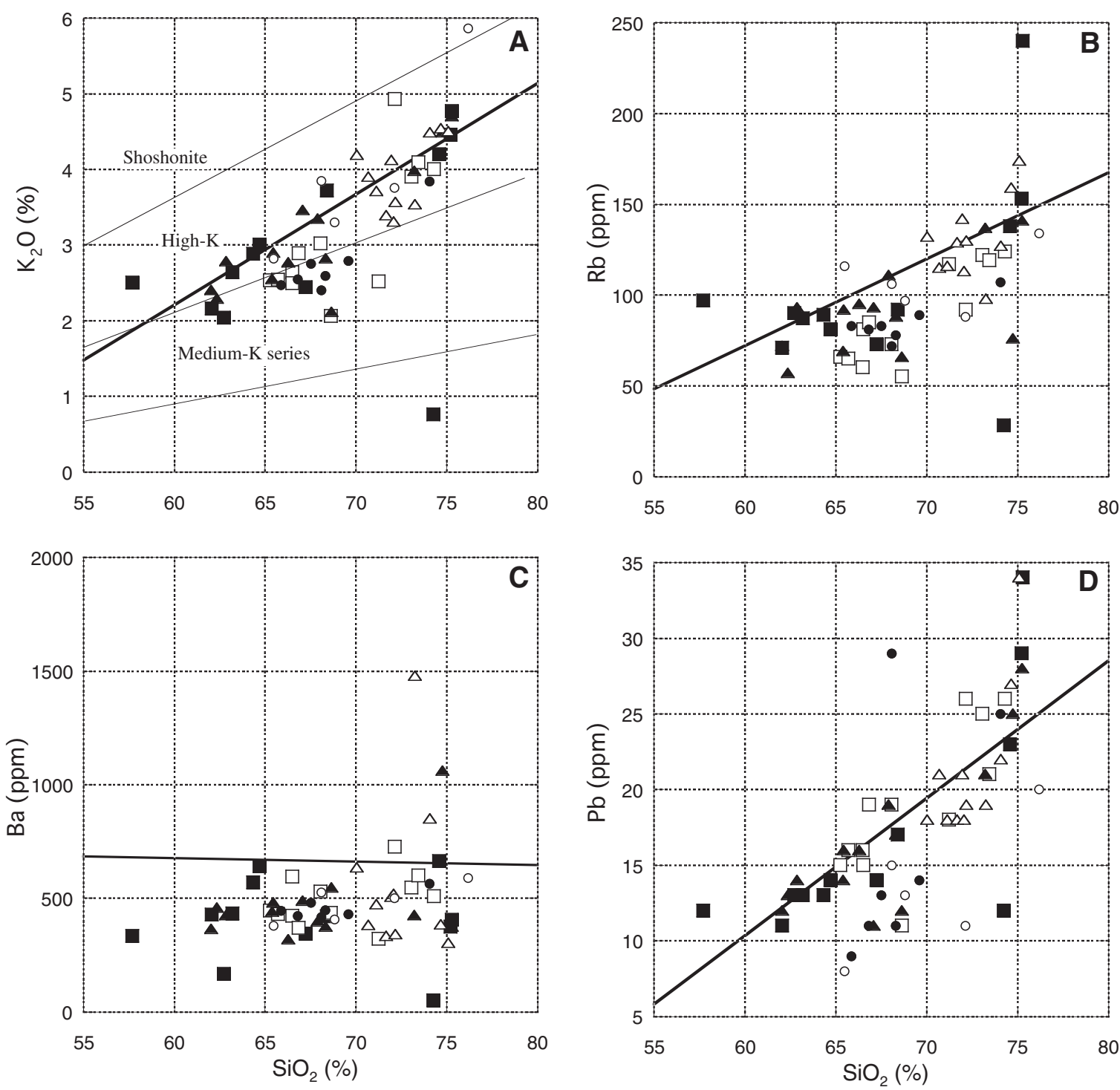

Fig. 5 Silica vs. $\mathrm{K}_{2} \mathrm{O}, \mathrm{Rb}, \mathrm{Ba}$ and $\mathrm{Pb}$ of the studied granitoids. Straight line is the regression line of the Ryoke granitoids. 


\section{Chemical compositions of the Abukuma granitoids}

The collected samples were crushed by a conventional special iron-made jaw crusher, a hand crusher and an agate motor. No tungsten contamination is expected. Powdered samples were analyzed by the polarized XRF method for the major and minor elements, $\mathrm{H}_{2} \mathrm{O}(+)$ was analyzed separately by a wet method; all analyzed by Bruce Chappell, Macquirie University, Sydney, Australia. The results are listed in the appendix.

The granitoids contain more than $55 \% \mathrm{SiO}_{2}$, implying that they are quartz diorite, tonalite, granodiorite and granite in composition. Mafic silicates are hornblende and biotite in quartz diorite to granodiorite, but only biotite in granitic composition. Muscovite-biotite granite, which is most close to the S-type by whole rock $\delta^{18} \mathrm{O}$ values (Ishihara and Matsuhisa, 2004), occurs in the west zone where the highest metamorphic temperature is assumed. Both major and minor elements of these granitoids are plotted in the Harker diagrams from Figs. 4 to 10.

The $\mathrm{Al}_{2} \mathrm{O}_{3}$ contents of the Abukuma granitoids are higher than those of the Ryoke granitoids (Fig. 4A), But the A/CNK values are below 1.1, implying that they belong to I-type

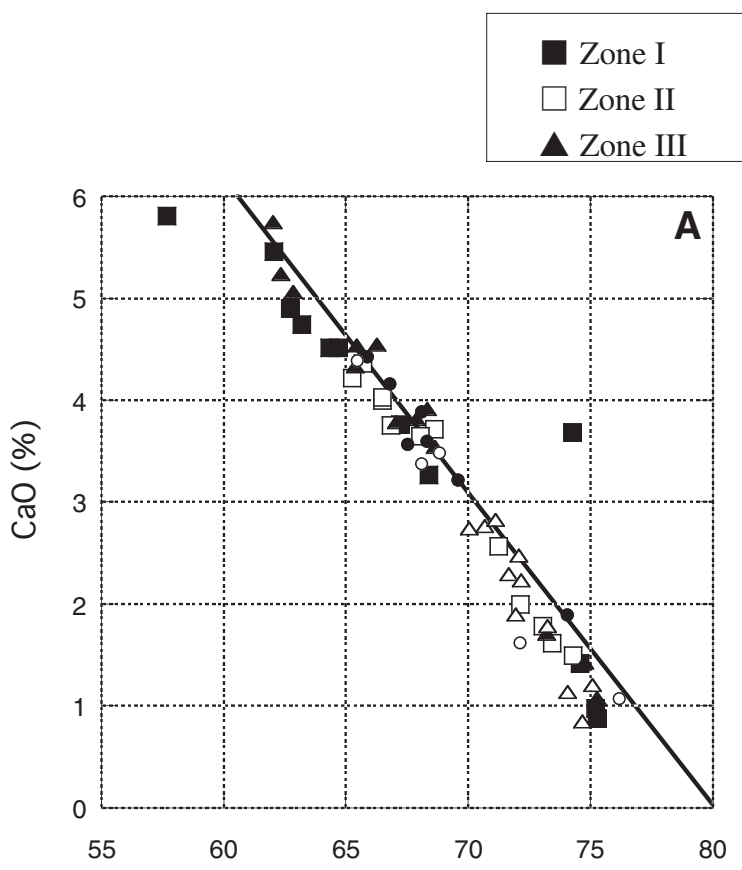

$\triangle$ Zone IV

- Zone V

Yaguki mine
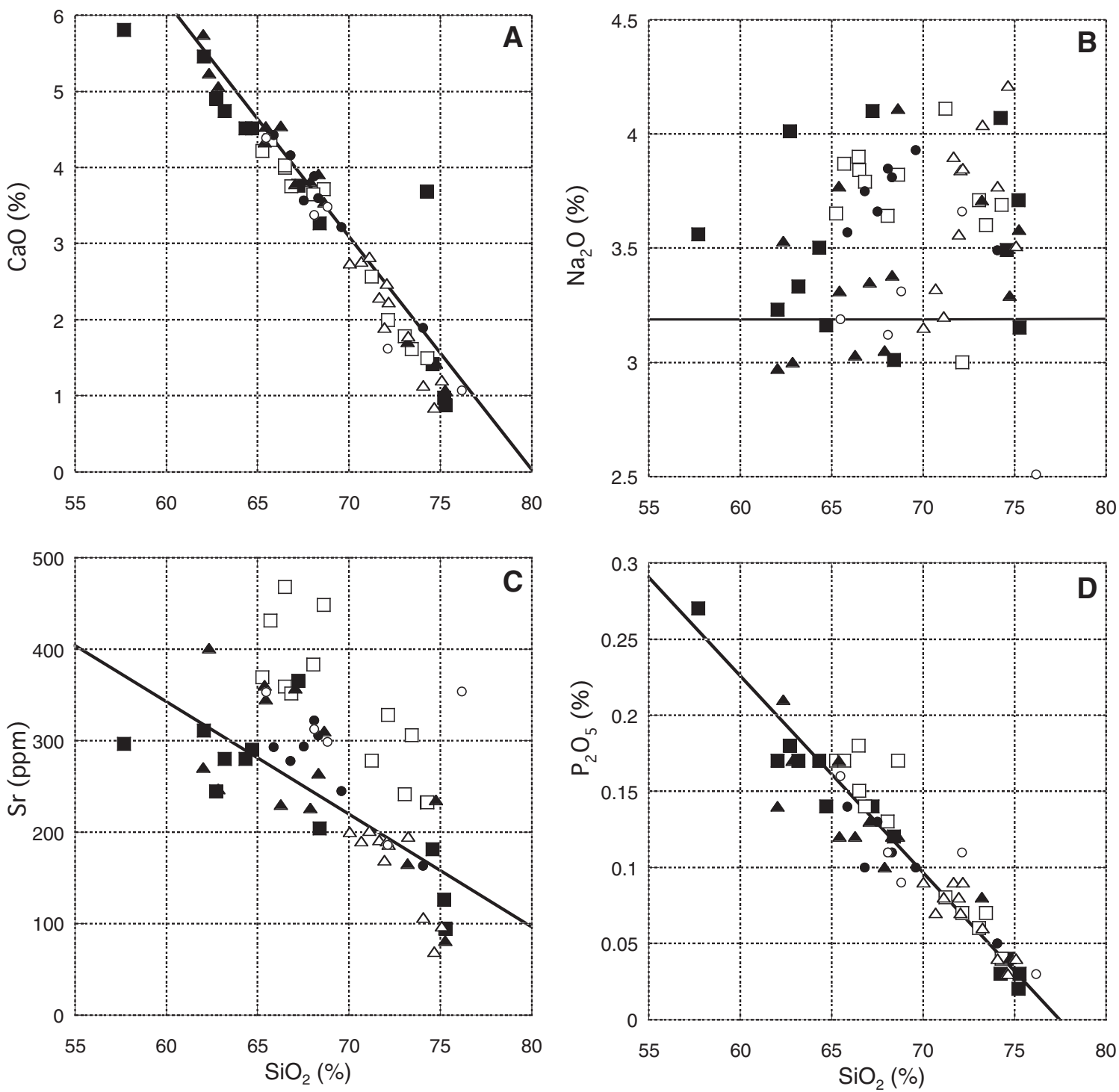

Fig. 6 Silica vs. $\mathrm{CaO}, \mathrm{Na}_{2} \mathrm{O}, \mathrm{Sr}$ and $\mathrm{P}_{2} \mathrm{O}_{5}$ of the studied granitoids. Straight line is the regression line of the Ryoke granitoids. 
ilmenite series. One high value of 1.15 (68A35) is garnetbearing muscovite-biotite granite. The other muscovitebiotite granites show also high values of 1.07 and 1.09. These granites are therefore closest to S-type of Chappell and White (1974), although their $\mathrm{K}_{2} \mathrm{O}$ contents are much lower than typical $\mathrm{S}$ type in Australia.

$\mathrm{Ga}$, which can replace $\mathrm{Al}$ in feldspars and may be a good indicator for the A-type granites, is generally lower than 21 ppm having Ga x 10000/A ratio lower than 2.6 (Fig. 4C, D). Within the low values, these content and ratio are regionally different in the distribution; those of the Zone II and parts of Zone I granitoids are higher than those of the Ryoke granitoids (Fig. $4 \mathrm{C}, \mathrm{D}$ ). $\mathrm{K}_{2} \mathrm{O}$ contents of these granitoids are slightly lower than those of the Ryoke average, plotted in the high-K to medium-K series fields (Fig. 5A). Among the five zones, the Zone $\mathrm{V}$ intermediate-series granitoids are least in the $\mathrm{K}_{2} \mathrm{O}$ contents.

$\mathrm{Rb}$ contents are generally lower than those of the Ryoke Belt. The Zone II granitoids are generally low in the $\mathrm{Rb}$ content. One high value (240 ppm, 68A35) is found in muscovite-biotite granite, and the low value of $28 \mathrm{ppm} \mathrm{Rb}$ is from the leuco-schlieren from the Ishikawa township (68A04). $\mathrm{Ba}$ and $\mathrm{Pb}$ contents are generally lower than those of the Ryoke granitoids. One extremely high value, $38 \mathrm{ppm}$

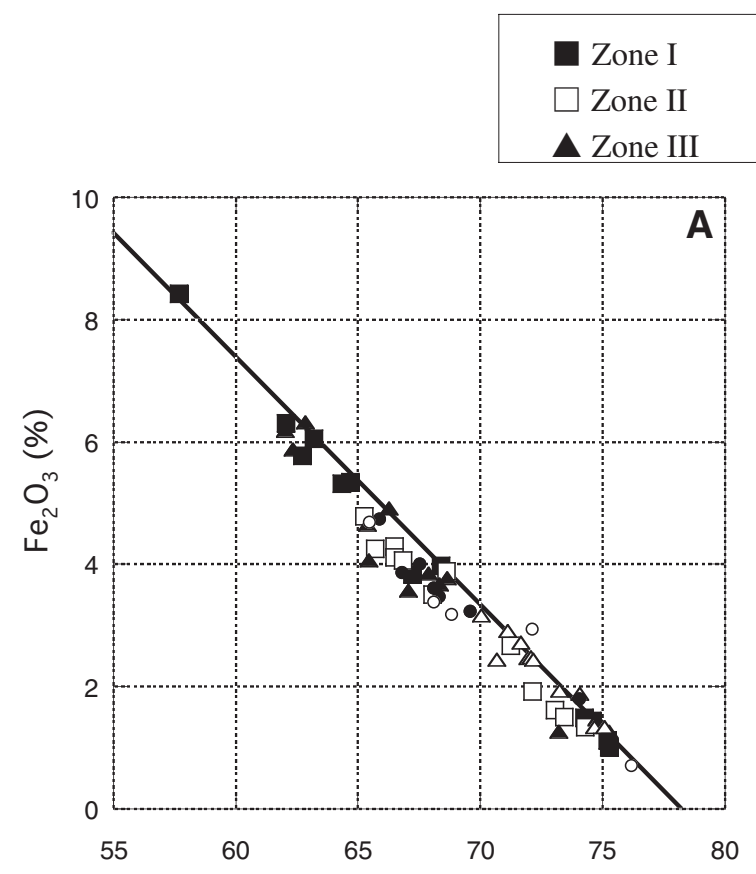

$\triangle$ Zone IV

- Zone V

$\bigcirc$ Yaguki mine
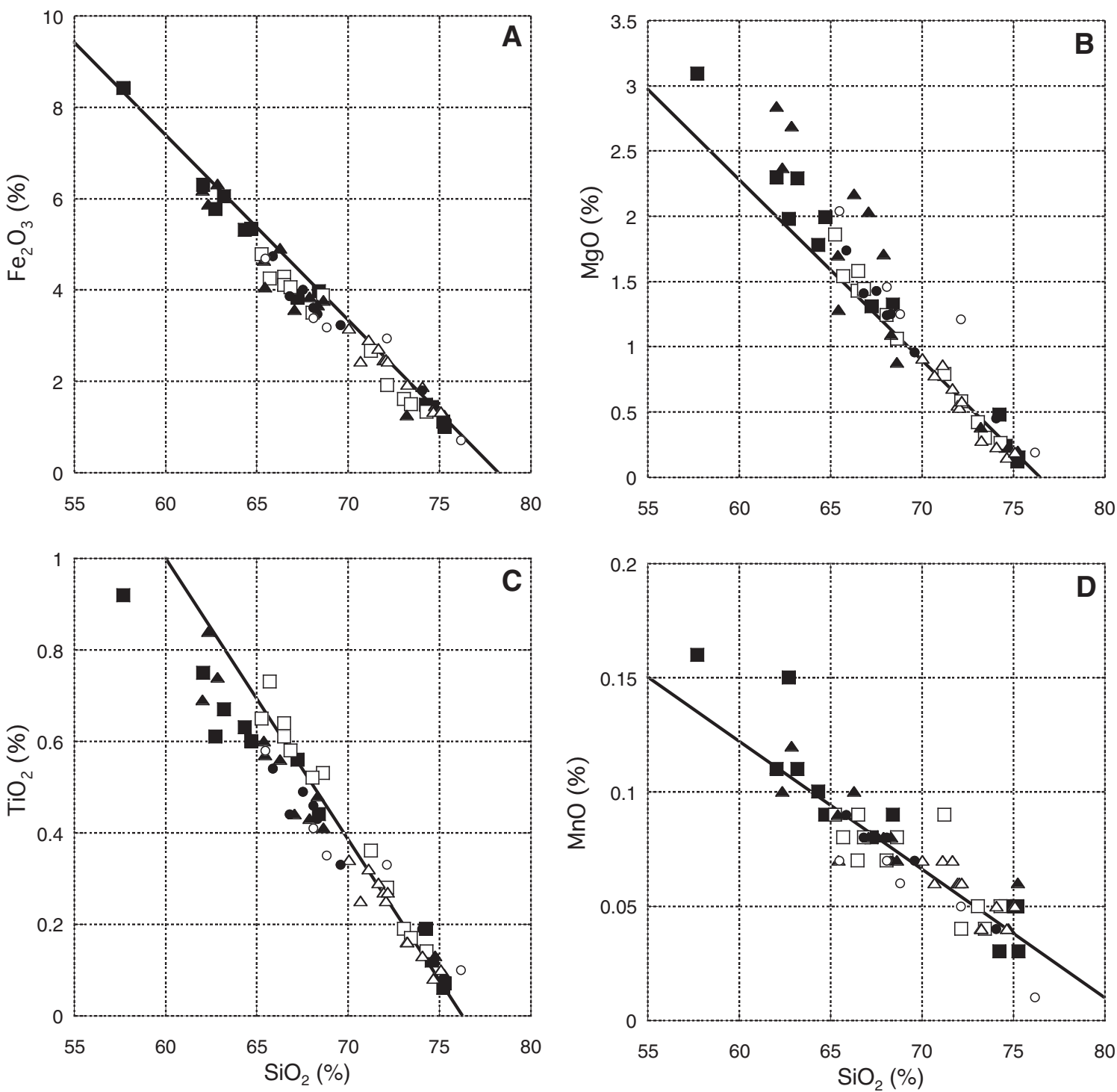

Fig. 7 Silica vs, $\mathrm{Fe}_{2} \mathrm{O}_{3}, \mathrm{MgO}, \mathrm{TiO}_{2}$ and $\mathrm{MnO}$ of the studied granitoids. Straight line is the regression line of the Ryoke granitoids. 
$\mathrm{Pb}$ (68A56), contains $137 \mathrm{ppm} \mathrm{Cu}$, and could be due to hydrothermal alteration.

$\mathrm{CaO}$ contents are slightly less than those of the Ryoke granitoids (Fig. 6A). One high value at $74.3 \% \mathrm{SiO}_{2}$ is from the leuco-schlieren (68A04). $\mathrm{Na}_{2} \mathrm{O}$ contents are generally higher than those of the Ryoke granitoids. The high values are observed in the Zone II granitoids. Sr contents are highest in the Zone II granitoids; accordingly their $\mathrm{Sr} / \mathrm{Y}$ ratio is high as 20 to 78 . Therefore the Zone II granitoids are most adakitic in the Abukuma Belt. Adakite has been discovered in the Cretaceous Kitakami Belt (Tsuchiya and Kanisawa, 1994). $\mathrm{P}_{2} \mathrm{O}_{5}$ contents are similar to those of the Ryoke granitoids.

$\mathrm{Rb} / \mathrm{Sr}$ ratio of these granitoids, which may indicates a degree of magmatic fractionation, is generally low (see appendix), being 0.1- 0.5 (average $0.3, \mathrm{n}=9$ ) in Zone I, 0.1 - 0.5 (average 0.3, $\mathrm{n}=12$ ) in Zone II, 0.1 - 0.8 (average 0.5, $\mathrm{n}=13$ ) in Zone III, 0.5 - 2.3 (average 1.0, $\mathrm{n}=11$ ), 0.2 - 0.7 (average 0.4) in Zone $\mathrm{V}$ and 0.3-0.5 (average 0.4, n=5) in Yaguki mine. In the Chubu district, W-related granite occurs just north of the Ryoke granitoids. Biotite granite of the Naegi West body, which hosts Ebisu wolframite-quartz veins with greisenization has much higher ratio between 21 and 41 (Ishihara and Murakami, 2006). Biotite granite related to the

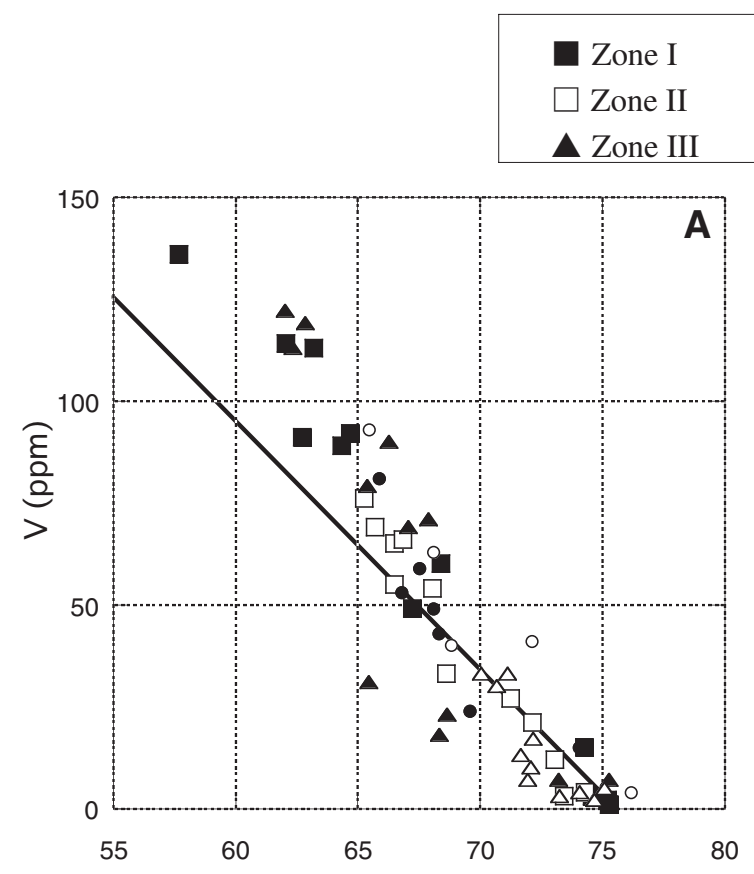

$\triangle$ Zone IV

- Zone V

$\bigcirc$ Yaguki mine
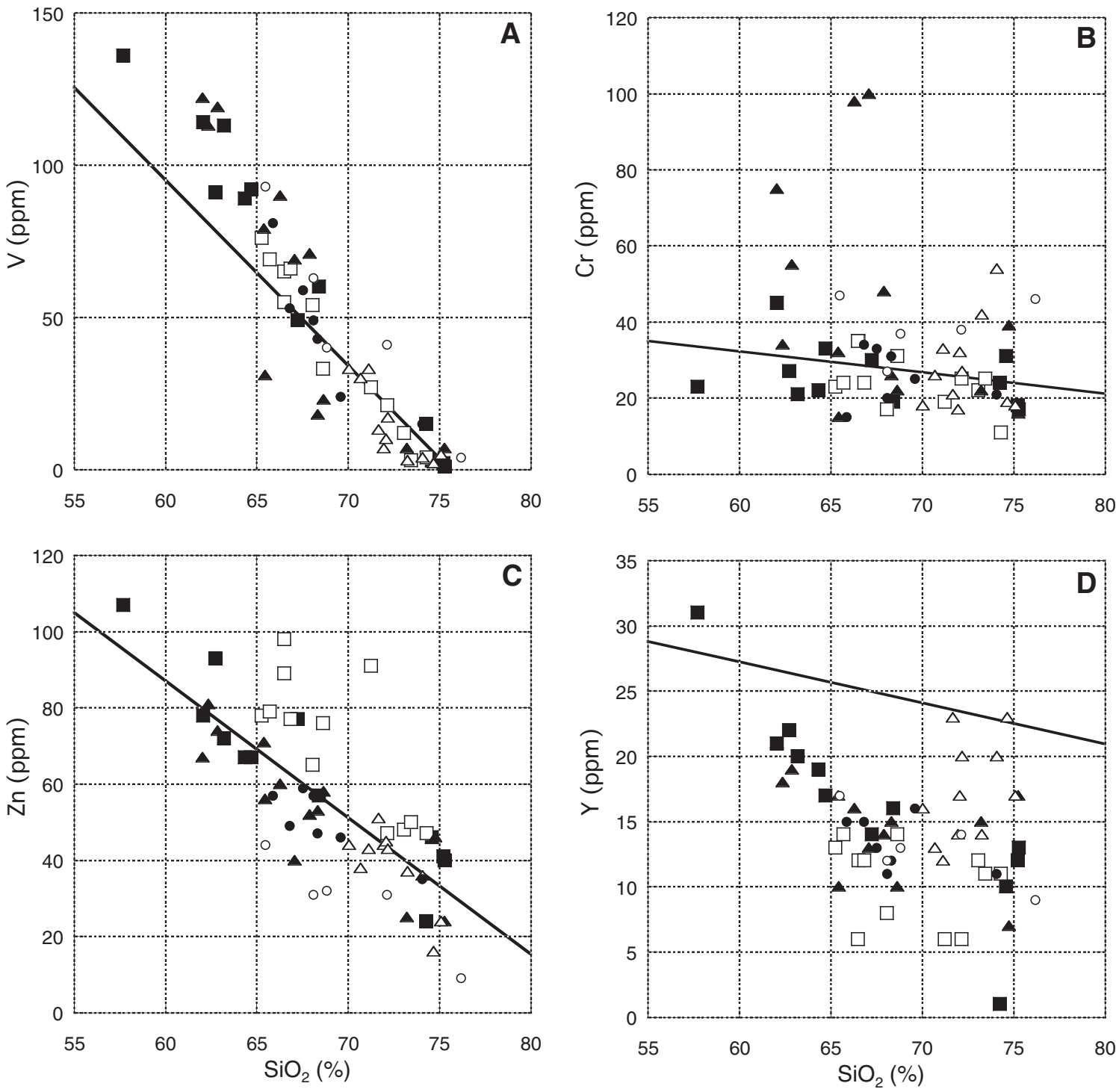

Fig. 8 Silica vs, V, Cr, Zn and Y of the studied granitoids. Straight line is the regression line of the Ryoke granitoids. 
Yaguki tungsten mineralization is felsic and reduced type, similarly to other $\mathrm{W}$-associated granites, but different having very low $\mathrm{Rb} / \mathrm{Sr}$ ratios and the lowest abundance of lithophile components.

Total iron contents as $\mathrm{Fe}_{2} \mathrm{O}_{3}$ (Fig. 7A) are slightly less than those of the Ryoke granitoids, except those of Zone II. Instead, $\mathrm{MgO}$ contents, especially of granodiorite composition and lower- $\mathrm{SiO}_{2}$ range rocks, are more than those of the Ryoke granitoids. The Zone III granitoids are most enriched in $\mathrm{MgO}$ (Fig. $5 \mathrm{~B}$ ). $\mathrm{TiO}_{2}$ contents are, on the other hand, weakly less in the low- $\mathrm{SiO}_{2}$ range rocks of the Abukuma Belt (Fig. 7C). MnO contents are similar to those of the Ryoke granitoids.

Among the trace elements substituting mafic major components such as $\mathrm{V}, \mathrm{Cr}, \mathrm{Co}, \mathrm{Ni}, \mathrm{Cu}$ and $\mathrm{Zn}$, the Abukuma granitoids have higher values in the low- $\mathrm{SiO}_{2}$ range granitoids, but lower values in the high- $\mathrm{SiO}_{2}$ range rocks, as compared with the average Ryoke granitoids. $\mathrm{Cr}$ contents are higher in most of the Zone III granitoids; the rest are similar to those of the Ryoke granitoids. $\mathrm{Zn}$ contents are similar to those of the Ryoke granitoids, but those of the Zone II granitoids are higher, and those of the Yaguki mine and Zone $\mathrm{V}$ are lower than the average Ryoke granitoids (Fig. $8 \mathrm{C})$. Y contents are very much low throughout the Abukuma

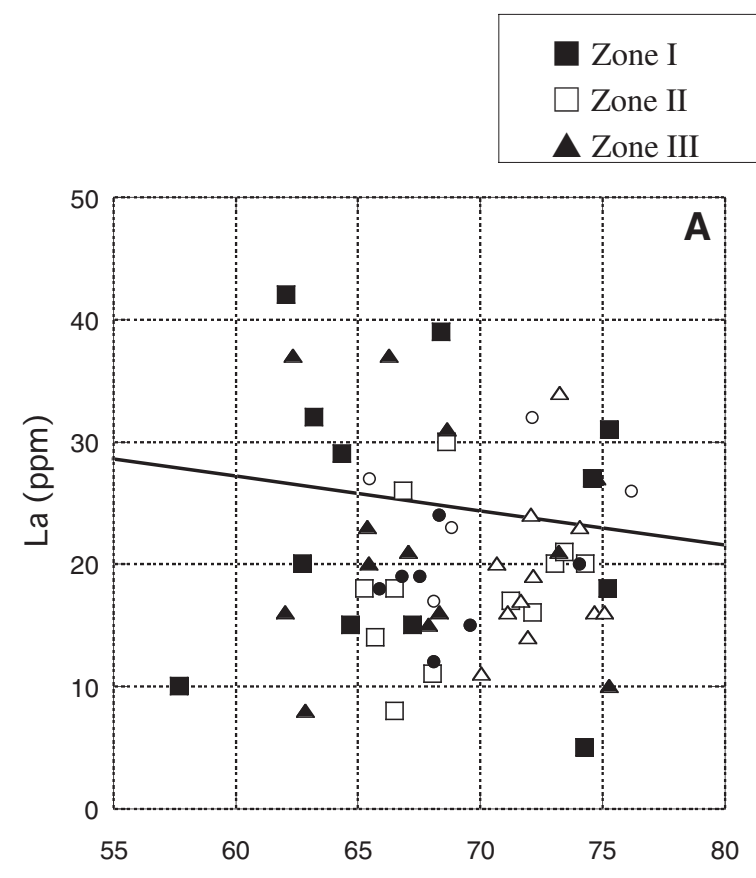

$\triangle$ Zone IV

- Zone V

Yaguki mine
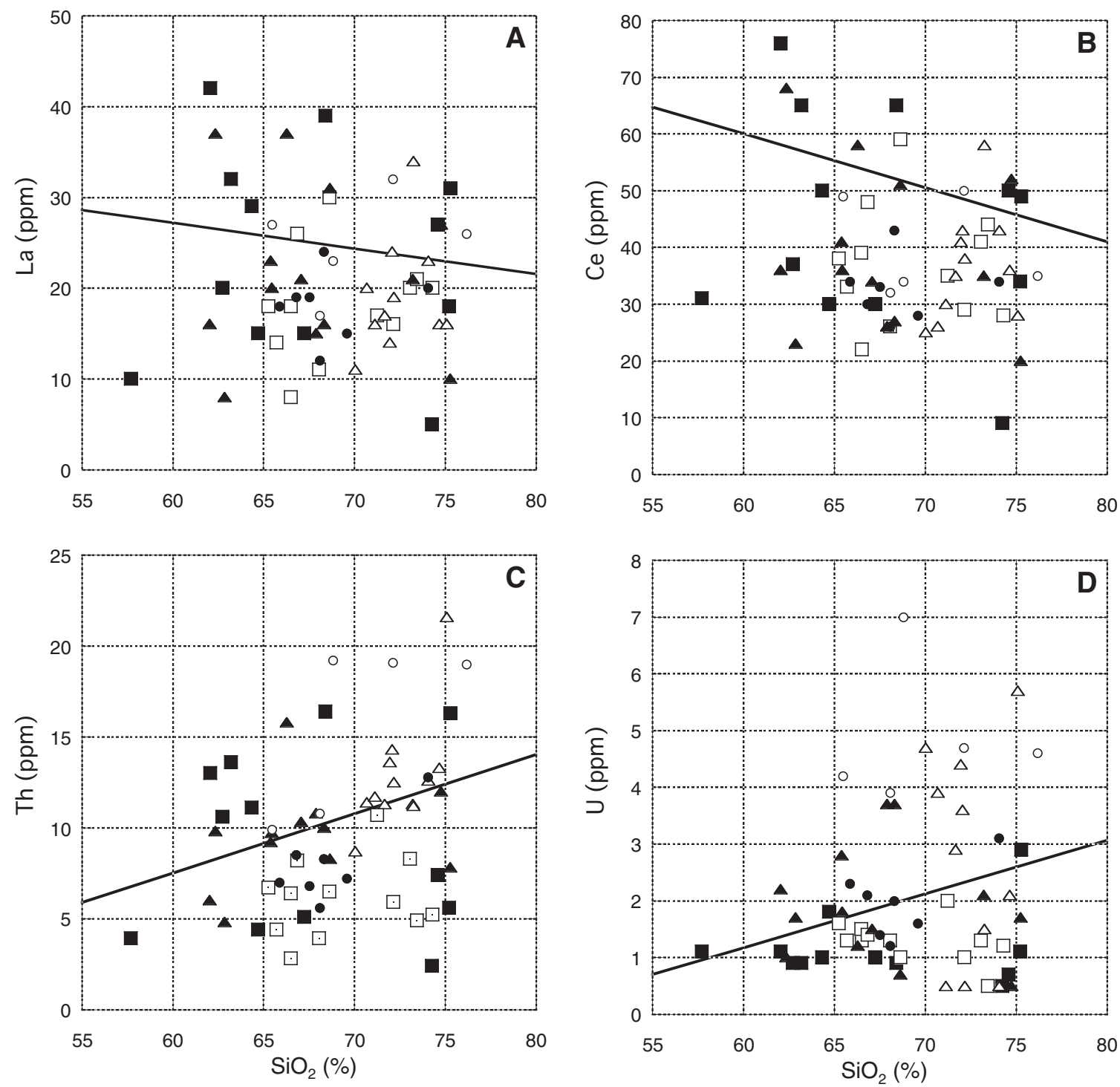

Fig. 9 Silica vs, La, Ce, Th, and U of the studied granitoids. Straight line is the regression line of the Ryoke granitoids. 
Belt; those of the Zone I granitoids are lowest in the $\mathrm{Y}$ contents (Fig. 8D).

Among REE and radioactive elements (Fig. 9), both $\mathrm{La}$ and $\mathrm{Ce}$ contents are lower than those of the Ryoke granitoids. The Zone II granitoids are least in these elements, particularly in Th (Fig, 9C) and U (Fig. 9D). The Zone IV granitoids are generally rich in Th and $\mathrm{U}$. The Yaguki mine granitoids are also rich in these radioactive elements.

$\mathrm{Nb}$ contents are similar to those of the Ryoke granitoids, as a whole, but are lowest in the Zone II granitoids (Fig. $10 \mathrm{~A})$. The contents are very erratic in the Zone I granitoids. $\mathrm{Zr}$ contents are lower than those of the Ryoke granitoids (Fig.
$10 \mathrm{~B})$, but the $\mathrm{Zr} / \mathrm{Hf}$ ratios, which would decrease in zircon by fractionation in meta- or per-aluminous magma (Linnenn and Keppler, 2002), are higher than those of the Ryoke granitoids (Fig. 10D). Zircon saturation temperatures (Watson and Harrison, 1983) are slightly lower than those of the Ryoke granitoids, varying from 760 to $715^{\circ} \mathrm{C}$. The felsic schlieren showed a low value of $668^{\circ} \mathrm{C}$.

\section{Summary and Interpretation}

As compared with the Ryoke granitoids of the Chubu district, the studied Abukuma granitoids have the following

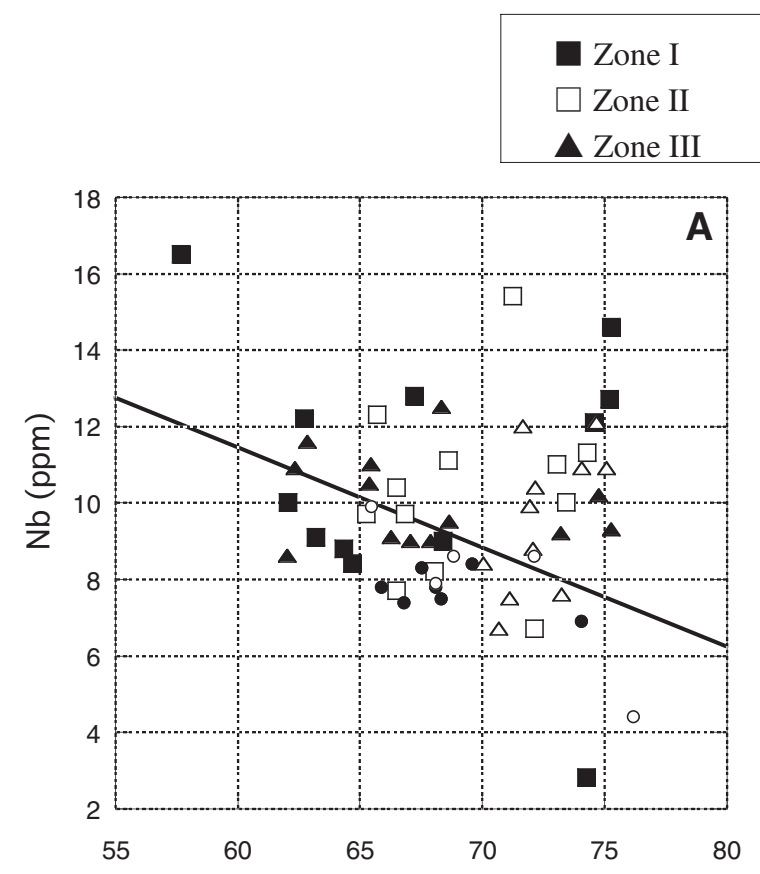

$\triangle$ Zone IV

- Zone V

Yaguki mine
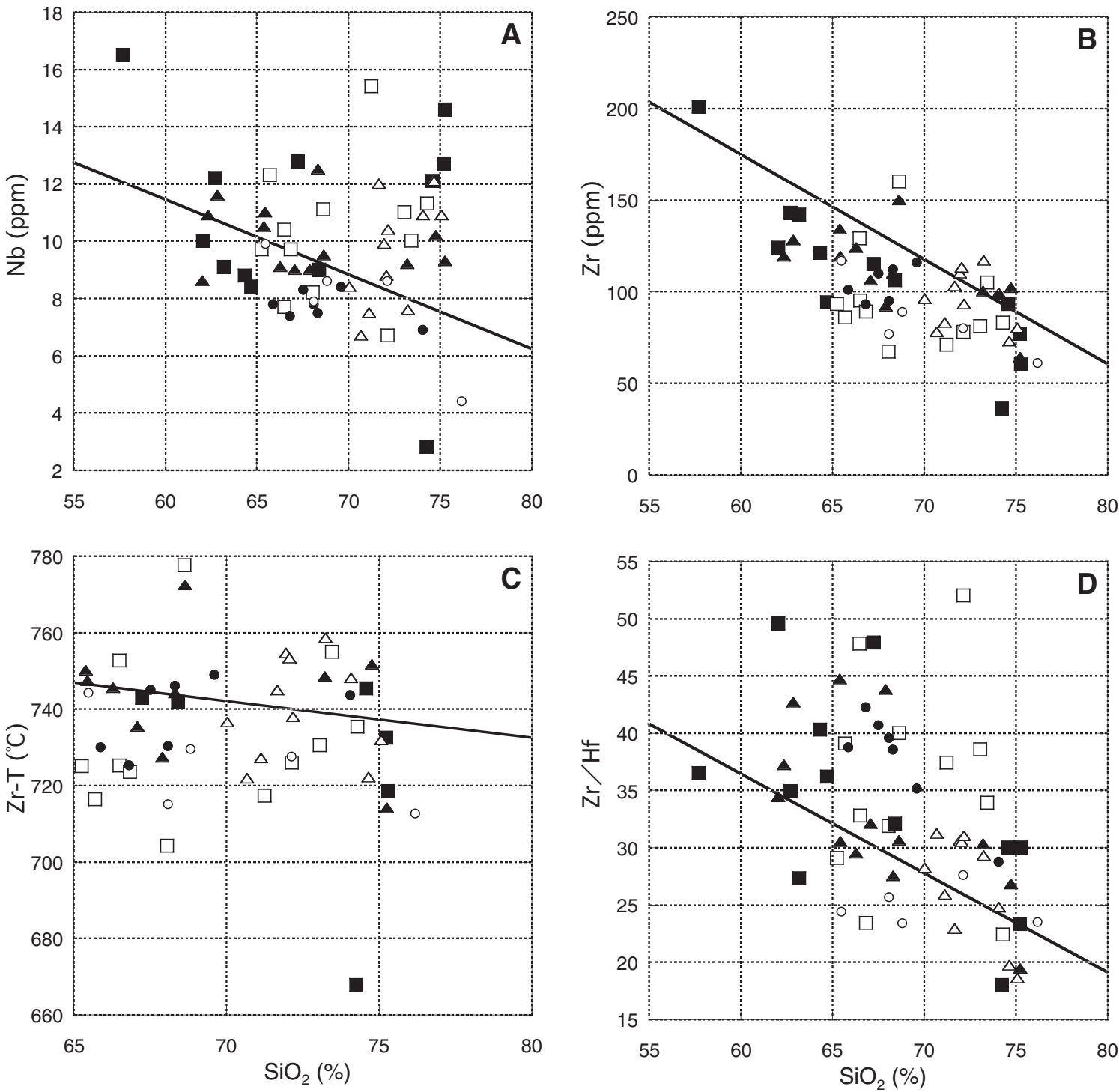

Fig. 10 Silica vs. $\mathrm{Nb}, \mathrm{Zr}, \mathrm{Zr} / \mathrm{Hf}$ and $\mathrm{Zr}$ saturation temperature of the studied granitoids. Straight line is the regression line of the Ryoke granitoids. 
chemical features:

(1) $\mathrm{Al}_{2} \mathrm{O}_{3}$ : higher, but shown less on the $\mathrm{A} / \mathrm{CNK}$,

(2) $\mathrm{K}_{2} \mathrm{O}$ : very low; least in Zone $\mathrm{V}$

(3) $\mathrm{Rb}, \mathrm{Ba}$ and $\mathrm{Pb}$ : lower, except the two-mica granite

(4) $\mathrm{Na}_{2} \mathrm{O}$ : higher,

(5) $\mathrm{CaO}$ weakly lower, but high in Zone II,

(6) Sr: much higher, especially in Zone II,

(7) $\mathrm{Rb} / \mathrm{Sr}$ ratio is consistently low,

(8) Total Fe: lower except for Zone II,

(9) $\mathrm{MgO}$ : higher in low $\mathrm{SiO}_{2}$ rocks, especially of Zone III

(10) $\mathrm{TiO}_{2}$ : weakly lower in low $\mathrm{SiO}_{2}$ rocks and Zone II,

(11) Y, Ce, (La): much lower, least in Zone II,

(12) U and Th: lower, except Zone IV and Yaguki mine.

The Abukuma granitoids are rich in $\mathrm{Al}_{2} \mathrm{O}_{3}$ and $\mathrm{Na}_{2} \mathrm{O}$, but poor in K-feldspar components, such as $\mathrm{K}_{2} \mathrm{O}, \mathrm{Rb}$ and $\mathrm{Pb}$. These chemical characteristics imply that the Abukuma granitoids were generated in a primitive island-arc and/ or oceanic I-type materials, while the Ryoke granitoids were originated in more felsic source rocks in a matured continental margin setting. Muscovite-biotite granite of Zone II has most S-type component, and is considered generated from $\mathrm{S}$ and I- type mingled source rocks in a middle continental crust, due to the highest heat flow recorded in the C-zone metamorphic rocks (Miyashiro, 1958). These differences in source rocks are also shown in their oxygen isotopic ratios discussed separately (e.g., Ishihara and Matsuhisa, 2004).

Zonal variation across the Abukuma terrain is best shown by oxidation status of these granitoids. Almost all the granitoids of the main part are reduced type, but higher $\mathrm{fO}_{2}$ of the intermediate series is distributed to the east of the Hatagawa sheared fault. Muscovite-biotite granite is also reduced having high $\delta^{18} \mathrm{O}$ values, which are originated in predominantly sedimentary source rocks (Ishihara and Matsuhisa, 2004).

Muscovite may occur commonly fractionated, high level parts of ilmenite-series biotite granite related to tin and tungsten mineralizations (e.g., Naegi Granite, Ishihara and Murakami, 2006; Yod Nam stock, southern Thailand, Ishihara et al., 1980; Hermingyi leucogranite, Myanmar, Cobbing et al., 1992), which have $\mathrm{Rb} / \mathrm{Sr}$ ratio of 21-41, 22-40 and 54-261, respectively. The Zone I muscovitebiotite granites have $\mathrm{Rb} / \mathrm{Sr}$ ratio between 0.8 and 2.6. These values are only weakly higher than those of hornblende and/ or biotite granitoids (see Appendix). Therefore, the granite is not a fractionated phase of biotite granite but is considered as remelting magma of sediment-bearing felsic I-type source rocks in a middle-upper continental crust.

Among ilmenite-series granitoids, Zone II granitoids are rich in $\mathrm{CaO}$ and $\mathrm{Sr}$, but depleted in lithophile components such as $\mathrm{Rb}, \mathrm{Y}$ and $\mathrm{Ce}$. These granitoids have the highest $\mathrm{Sr} / \mathrm{Y}$ ratios of $20-78$, whose ratio may be one of good indicators for the adakite (Defant and Kepezhinskas, 2001). Gabbroids are fairly abundant in the Abukuma terrain, as mentioned previously. Thus, the mafic magmas were brought into the terrain from the upper mantle. Adakitic magmas from the subducting slab may also have been brought up to the terrain; yet magma interaction and mingling within the continental crust must have modified the original composition, thus erased the original characteristics.

Acknowledgement: Careful reviewing by Dr. T. Takagi and technical assistance of Ms. H. Shimizu are greatly acknowledged.

\section{References}

Abe, T. and Ishihara, S. (1985) Chemical composition of tonalites from Matsukawa-ura, northeastern Abukuma Highland. Bull. Geol. Surv. Japan, 36, 167-171 (in Japanese with English abstract).

Chappell, B. W. and White, A. J. R. (1974) Two contrasting granite type. Pacific Geol. no. 8, 173-174.

Cobbing, E. J., Pitfield, P. E. J., Darbyshire, D. P. F. and Wallick, D. I. (1992) The granites of the South-East Asian tin belt. British Geol. Surv., Overseas Mem. 10, $369 \mathrm{p}$.

Defant, M. J. and Kepezhinskas, P. (2001) Evidence suggests slab melting in arc magmas. EOS, no. 82, 65-80.

Hiroi, Y., Yokose, M., Oba, T., Nohara, T. and Yao, A. (1987) Discovery of Jurassic radiolarian from acmite-bearing metachert of the Gosaisyo metamorphic rocks in the Abukuma terrane, northestern Japan. Jour. Geol. Soc. Japan, 93, 445-448.

Ishihara, S. (1990) The Inner Zone batholith vs. the Outer Zone batholith of Japan: Evaluation from their magnetic susceptibilities. Univ. Museum, Univ. Tokyo, Nature \& Culture, no. 2, 21-34

Ishihara, S. (2002) Chemical characteristics of the mineralized granitoids (II): Polymetallic province of the west-central Hyogo Prefecture. Bull. Geol. Surv. Japan, 53, 673-688.

Ishihara, S. and Chappell, B. W. (2007) Chemical compositions of the late Cretaceous Ryoke granitoids of the Chubu District, central Japan. Bull. Geol. Surv. Japan, 58, 323-350.

Ishihara, S. and Matsuhisa, Y. (2004) Oxygen isotopic constraints on the genesis of the Cretaceous granitoids 
in the Kitakami and Abukuma terrains, Northeast Japan. Bull. Geol. Surv. Japan, 55, 57-66.

Ishihara, S. and Murakami, H. (2006) Fractionated ilmeniteseries granites in Southwest Japan: Source magma for REE-Sn-W mineralizations. Resource Geol., 56, 245-256.

Ishihara, S., Shibata, K. and Uchiumi, S. (1988) K-Ar ages of ore deposits related to Cretaceous-Paleogene granitoidsSummary in 1987. Bull. Geol. Surv. Japan, 39, 81-94 (in Japanese with English abstract).

Ishihara, S., Hattori, H., Sakamaki, Y., Kanaya, H., Sato, T., Mochizuki, T. and Terashima, S. (1973) Lateral chemical variation of the granitic rocks and metamorphic rocks across the central Abukuma Highland-With emphasis on the contents of uranium, thorium and potassium. Bull. Geol. Surv. Japan, 24, 269-284 (in Japanese with English abstract).

Ishihara, S., Sawata, H., Shibata, K., Terashima, S. Arrykul, S. and Sato, K. (1980) Granites and Sn-W deposits of Peninsular Thailand. Mining Geology Special Issue, no. 8, 223-242.

Kamei, A. and Takagi, T. (2003) Geology and petrography of the Abukuma granites in the Funehiki area, Fukushima Prefecture. Jour. Geol. Soc. Japan, 109, 234-251 (in Japanese with English abstract).

Kubo, K. (1991) Black Mikage (gabbroids) and white Mikage (granitoids) of the Abukuma Mountains. Chishitsu News, no. 441, 28-33 (in Japanese).

Kubo, K. and Yamamoto, T. (1990) Cretaceous intrusive rocks of the Haramachi district, eastern margin of the Abukuma Mountains - Petrography and K-Ar age.Jour. Geol. Soc. Japan, 96, 731-743 (in Japanese with English abstract).

Kubo, K., Yanagisawa, Y., Yamamoto, T., Komazawa, M., Hiroshima, T. and Sudo, S. (2003) Geological map of Japan 1:200,000, Fukushima. Geol. Surv. Japan.

Linnenn, R. L. and Keppler, H. (2002) Melt composition control of $\mathrm{Zr} / \mathrm{Hf}$ fractionation in magmatic processes. Geochim. Cosmochim Acta, 66, 3293-3301.

Miyashiro, A. (1958) Regional metamorphism of the Gosaisho-Takanuki District in the central Abukuma Plateau. Jour. Fac. Sci., Univ. Tokyo, Sec. II, 11, 219272.

Miyashiro, A. (1965) Metamorphic rocks and metamorphic belts. Iwanami-shoten, Tokyo, 458 p. (in Japanese).
Muramatsu, Y. and Nanbu, M. (1975) Mineralization of pyrrhotite at the Yaguki mine, Fukushima prefecture, Japan. Prof. T. Takeuchi Retirement Vol., 151-162 (in Japanese with English abstract).

Nittetsu Mining Co. (1965) Yaguki mine. In List of Ore Deposits in Japan. Vol. I, Japan Mining Industry Assoc., 163-166 (in Japanese).

Ogawa, K. and Shida, A. (1975) Sheelite mineralization in the Shin-bu tungsten deposit of the Yaguki mine. Mining Geol., 25, 109-122 (in Japanese with English abstract).

Shibata, K. and Ishihara, S. (1979) Initial ${ }^{86} \mathrm{Sr} /{ }^{87} \mathrm{Sr}$ ratios of plutonic rocks from Japan. Contrib. Mineral. Petrol., 70, 381-390.

Shibata, K. and Tanaka, T. (1987) Age of formation for the Ishikawa composite mass, Abukuma Mountains, inferred from $\mathrm{Nd}$ and $\mathrm{Sr}$ isotopic systematics. Jour. Japan. Assoc. Min. Petr. Econ. Geol., 82, 433-440.

Shimazaki, H. (1969) Pyrometasomatic copper and iron deposits of the Yaguki mine, Fukushima Prefecture, Japan. Jour. Fac. Sci., Univ. Tokyo, Sec. II, 17, 317-350.

Shoji, T., Shida, A., Cho, H. and Matsuoka, T. (1975) Structural features near the Yaguki mine, Fukushima Prefecture, Japan. Mining Geol., 25, 1-10 (in Japanese with English abstract).

Takahara, H. and Nakano, T. (1993) Formation of endoskarn and scheelite at the Tenpo orebody of the Yaguki mine, northeastern Japan. Resource Geol., 43, 267-282.

Tsuchiya, N. and Kanisawa, S. (1994) Early Cretaceous Srrich silisic magmatism by slab-melting in the Kitakami Mountains, Northeast Japan. Jour. Geophy. Res., 99, 22,205-22,220.

Watanabe, I., Gorai, M., Kuroda, Y., Ono, K. and Togawa, T. (1955) Igneous activities of the Abukuma Plateau: Part 9, Earth Sci. no. 24, 1-11 (in Japanese with English abstract).

Watson, E. B. and Harrison, T. M. (1983) Zircon saturation revisited: temperature and composition effects in a variety of crustal magma types. Earth Planet. Sci. Let., 64, 295-304

Yoshimura, T. and Miyamoto, H. (1954) Manganese. In Mineral Resources of Japan, BI-c, Geol. Surv. Japan, 56-102 (in Japanese).

Received March 05, 2008

Accepted April 23, 2008 


\title{
阿武隈高原中央部の後期白亜紀花崗岩類の化学組成の横断面変化一再検討
}

\author{
石原舜三 ・ブルース W. チャペル ${ }^{2}$
}

要旨

阿武隈高原の中央部で後期白亜紀の花崗岩類の主成分と微量成分とを偏光蛍光分析法により分析し、 中部地方の領家花崗岩類との比較を試みた。阿武隈花崗岩類は角閃石 - 黒雲母花崗閃緑岩〜黒雲母花崗 岩が主体で、中部地方に多い白雲母 - 黒雲母花崗岩類は少ない。阿武隈花崗岩類はハーカー図上でナト リウムとアルミニウムに富み、カリウム・ルビジウム・鉛・バリウムなどにそしい。これらの性質は、 阿武隈花崗岩質マグマは上部マントルからのマグマや熱の供給を受けて、成熟度が低い島弧地殼で生成 した可能性を示している。

阿武隈花崗岩類は中部地方と同様に、地凯起源炭素により還元されたチタン鉄鉱系から主に構成され るが、一部とくに最東部で磁鉄鉱を含む中間系列花崗岩類が産出する。その近傍の八茥タングステン鉱 床直下の黒雲母花崗岩はチタン鉄鉱系であり、中部地方の苗木花崗岩におけると同様にタングステン鉱 床は還元的花崗岩と成因的に密接である。第 II 帯の花崗岩類はハーカー図上でカルシウムに富み、カリ ウム・ルビジウム・鉛・イットリウム・セリウム・ランタンなどにそしい。ここではやや高い $\mathrm{Sr} / \mathrm{Y} か ゙$ 得られており、深所からのアダカイト質珪長質マグマの供給が考えられるが、大陸地殼通過時に地殼起 源マグマと反応した可能性が大きい。 
Appendix-1: Chemical compositions of the studied granitoids including two gabbroids in the Abukuma Highland. The granitoids were classified into five zones from west to east, and Yaguki mine underground.

\begin{tabular}{|c|c|c|c|c|c|c|c|c|c|c|c|}
\hline & \multicolumn{2}{|c|}{ Gabbroid } & \multicolumn{4}{|c|}{ Zone I : Ishikawa granodiorite } & \multirow[b]{2}{*}{ 68A11 } & \multirow[b]{2}{*}{$68 \mathrm{~A} 13$} & \multirow[b]{2}{*}{$68 \mathrm{~A} 36$} & \multirow[b]{2}{*}{$68 \mathrm{~A} 41$} & \multirow[b]{2}{*}{ 68А39 } \\
\hline & $72 \mathrm{~A} 233$ & $68 \mathrm{~A} 12$ & $68 \mathrm{~A} 01$ & $68 \mathrm{~A} 02$ & $68 \mathrm{~A} 03$ & $68 \mathrm{~A} 04$ & & & & & \\
\hline Mag. Sus. & $0.8-62.3$ & 0.65 & 0.57 & 0.55 & 0.53 & 0.39 & 0.98 & 2.05 & 0.74 & 0.47 & 0.52 \\
\hline $\mathrm{SiO} 2$ & 44.33 & 52.50 & 57.71 & 62.74 & 68.42 & 74.26 & 62.06 & 64.71 & 63.21 & 64.35 & 67.25 \\
\hline $\mathrm{TiO} 2$ & 1.82 & 0.75 & 0.92 & 0.61 & 0.44 & 0.19 & 0.75 & 0.60 & 0.67 & 0.63 & 0.56 \\
\hline $\mathrm{Al} 2 \mathrm{O} 3$ & 17.67 & 13.55 & 17.14 & 16.70 & 14.64 & 14.26 & 16.38 & 15.80 & 15.81 & 16.30 & 15.63 \\
\hline $\mathrm{Fe} 2 \mathrm{O} 3$ & 14.06 & 9.33 & 8.42 & 5.77 & 3.96 & 1.48 & 6.30 & 5.34 & 6.05 & 5.31 & 3.83 \\
\hline $\mathrm{MnO}$ & 0.19 & 0.17 & 0.16 & 0.15 & 0.09 & 0.03 & 0.11 & 0.09 & 0.11 & 0.10 & 0.08 \\
\hline $\mathrm{MgO}$ & 7.68 & 9.41 & 3.09 & 1.98 & 1.32 & 0.48 & 2.30 & 1.99 & 2.29 & 1.78 & 1.31 \\
\hline $\mathrm{CaO}$ & 11.79 & 12.03 & 5.80 & 4.90 & 3.26 & 3.68 & 5.45 & 4.51 & 4.74 & 4.51 & 3.76 \\
\hline $\mathrm{Na} 2 \mathrm{O}$ & 1.35 & 1.26 & 3.56 & 4.01 & 3.01 & 4.07 & 3.23 & 3.16 & 3.33 & 3.50 & 4.10 \\
\hline K2O & 0.35 & 0.33 & 2.50 & 2.04 & 3.72 & 0.76 & 2.16 & 3.00 & 2.64 & 2.88 & 2.44 \\
\hline P2O5 & 0.04 & 0.09 & 0.27 & 0.18 & 0.12 & 0.03 & 0.17 & 0.14 & 0.17 & 0.17 & 0.14 \\
\hline S & 0.17 & 0.13 & $<0.01$ & $<0.01$ & $<0.01$ & $<0.01$ & $<0.01$ & $<0.01$ & $<0.01$ & $<0.01$ & $<0.01$ \\
\hline $\mathrm{H} 2 \mathrm{O}+$ & 1.15 & 0.23 & 0.64 & 0.81 & 0.96 & 0.47 & 1.10 & 0.72 & 0.98 & 0.49 & 0.78 \\
\hline H2O- & 0.01 & 0.48 & 0.30 & 0.21 & 0.18 & 0.32 & 0.23 & 0.11 & 0.28 & 0.34 & 0.16 \\
\hline $\mathrm{CO} 2$ & 0.12 & 0.08 & 0.02 & 0.23 & 0.17 & 0.19 & 0.10 & 0.08 & 0.02 & 0.02 & 0.11 \\
\hline SUM & 100.73 & 100.28 & 100.53 & 100.33 & 100.29 & 100.22 & 100.34 & 100.25 & 100.30 & 100.38 & 100.15 \\
\hline $\mathrm{Rb}$ & 8 & 2.8 & 97 & 90 & 92 & 28 & 71 & 81 & 87 & 89 & 73 \\
\hline $\mathrm{Sr}$ & 393 & 180 & 296 & 244 & 204 & 232 & 311 & 290 & 280 & 280 & 365 \\
\hline $\mathrm{Ba}$ & 62 & 43 & 334 & 166 & 419 & 50 & 428 & 640 & 432 & 569 & 344 \\
\hline $\mathrm{Zr}$ & 26 & 47 & 201 & 143 & 106 & 36 & 124 & 94 & 142 & 121 & 115 \\
\hline $\mathrm{Hf}$ & $<2.7$ & $<2.0$ & 5.5 & 4.1 & 3.3 & $<2.0$ & 2.5 & 2.6 & 5.2 & 3 & 2.4 \\
\hline $\mathrm{Nb}$ & 3.5 & 4.6 & 16.5 & 12.2 & 9 & 2.8 & 10 & 8.4 & 9.1 & 8.8 & 12.8 \\
\hline $\mathrm{Ta}$ & $<4.8$ & $<2.0$ & $<2.0$ & $<2.0$ & 2.2 & 2.3 & 2.4 & $<2.0$ & 4.4 & $<2.2$ & $<1.9$ \\
\hline Y & 14 & 19 & 31 & 22 & 16 & 1 & 21 & 17 & 20 & 19 & 14 \\
\hline La & 4 & 10 & 10 & 20 & 39 & 5 & 42 & 15 & 32 & 29 & 15 \\
\hline $\mathrm{Ce}$ & 9 & 31 & 31 & 37 & 65 & 9 & 76 & 30 & 65 & 50 & 30 \\
\hline V & 451 & 327 & 136 & 91 & 60 & 15 & 114 & 92 & 113 & 89 & 49 \\
\hline $\mathrm{Cr}$ & 39 & 787 & 23 & 27 & 19 & 24 & 45 & 33 & 21 & 22 & 30 \\
\hline Co & 47 & 35 & 12 & 13 & 8 & 8 & 10 & 12 & 13 & 12 & 8 \\
\hline $\mathrm{Ni}$ & 16 & 46 & 4 & 2 & 1 & $<1$ & 2 & 2 & 2 & $<1$ & 1 \\
\hline $\mathrm{Cu}$ & 53 & 57 & 18 & 3 & 3 & 11 & 18 & 4 & 11 & 8 & 3 \\
\hline $\mathrm{Zn}$ & 104 & 77 & 107 & 93 & 57 & 24 & 78 & 67 & 72 & 67 & 77 \\
\hline $\mathrm{Pb}$ & 1 & 4 & 12 & 13 & 17 & 12 & 11 & 14 & 13 & 13 & 14 \\
\hline $\mathrm{Ga}$ & 17.8 & 14.3 & 21 & 18.5 & 14.2 & 12.7 & 17.4 & 15.4 & 15.5 & 17.2 & 21.1 \\
\hline $\mathrm{Ge}$ & 1.4 & 1.7 & 1.8 & 1.6 & 1.6 & 1.2 & 1.3 & 1.1 & 1.5 & 1.5 & 1.4 \\
\hline As & 0.4 & $<0.3$ & $<0.3$ & 0.9 & 1.2 & 0.7 & 0.5 & $<0.3$ & $<0.3$ & 0.7 & 0.7 \\
\hline $\mathrm{Se}$ & $<0.2$ & 0.2 & 0.2 & $<0.2$ & 0.2 & 0.2 & 0.2 & $<0.2$ & $<0.2$ & $<0.1$ & $<0.1$ \\
\hline Mo & 0.5 & 0.2 & 0.4 & $<0.2$ & $<0.2$ & $<0.2$ & 0.9 & 0.3 & 0.4 & $<0.2$ & 0.5 \\
\hline W & $<1.9$ & $<1.0$ & $<1.0$ & $<1.0$ & $<1.0$ & $<1.0$ & $<1.0$ & $<1.0$ & $<1.0$ & $<1.2$ & $<1.2$ \\
\hline Sn & $<0.4$ & 0.5 & 2.3 & 3.1 & 1.2 & $<0.4$ & 1.3 & 1.1 & 1.9 & 1.7 & 2.5 \\
\hline $\mathrm{Cd}$ & 0.5 & 0.4 & 0.5 & $<0.2$ & $<0.2$ & $<0.2$ & $<0.2$ & 0.5 & 0.4 & 0.4 & $<0.2$ \\
\hline $\mathrm{Sb}$ & $<0.5$ & $<0.5$ & $<0.5$ & $<0.5$ & $<0.5$ & $<0.5$ & $<0.5$ & $<0.5$ & $<0.5$ & $<0.5$ & 0.4 \\
\hline $\mathrm{TI}$ & $<0.7$ & $<0.7$ & $<0.7$ & $<0.7$ & 0.7 & $<0.7$ & $<0.7$ & $<0.7$ & 0.7 & 0.4 & $<0.5$ \\
\hline $\mathrm{Bi}$ & $<0.4$ & $<0.5$ & $<0.5$ & $<0.5$ & $<0.5$ & $<0.5$ & $<0.5$ & $<0.5$ & $<0.5$ & $<0.3$ & $<0.3$ \\
\hline Th & 0.6 & 3. & 3.9 & 10.6 & 16.4 & 2.4 & 13 & 4.4 & 13.6 & 11.1 & 5.1 \\
\hline U & 1.1 & 1.9 & 1.1 & 0.9 & 0.9 & $<0.5$ & 1.1 & 1.8 & 0.9 & 1 & 1 \\
\hline$\overline{\mathrm{A} / \mathrm{CNK}}$ & 0.74 & 0.56 & 0.90 & 0.94 & 0.98 & 1.00 & 0.93 & 0.95 & 0.93 & 0.95 & 0.96 \\
\hline $\mathrm{Ga}^{*} 10000 / \mathrm{A}$ & 1.9 & 2.0 & 2.3 & 2.1 & 1.8 & 1.7 & 2.0 & 1.8 & 1.9 & 2.0 & 2.6 \\
\hline $\mathrm{Rb} / \mathrm{Sr}$ & 0.0 & 0.0 & 0.3 & 0.4 & 0.5 & 0.1 & 0.2 & 0.3 & 0.3 & 0.3 & 0.2 \\
\hline $\mathrm{Sr} / \mathrm{Y}$ & 28.1 & 9.5 & 9.5 & 11.1 & 12.8 & 232.0 & 14.8 & 17.1 & 14.0 & 14.7 & 26.1 \\
\hline $\mathrm{Zr} / \mathrm{Hf}$ & 9.6 & 23.5 & 36.5 & 34.9 & 32.1 & 18.0 & 49.6 & 36.2 & 27.3 & 40.3 & 47.9 \\
\hline $\mathrm{Zr}-\mathrm{T}\left({ }^{\circ} \mathrm{C}\right)$ & 573.0 & 584.9 & 766.2 & 751.7 & 742.0 & 667.7 & 739.1 & 723.2 & 752.4 & 742.2 & 743.0 \\
\hline
\end{tabular}


Appendix-1: Continued

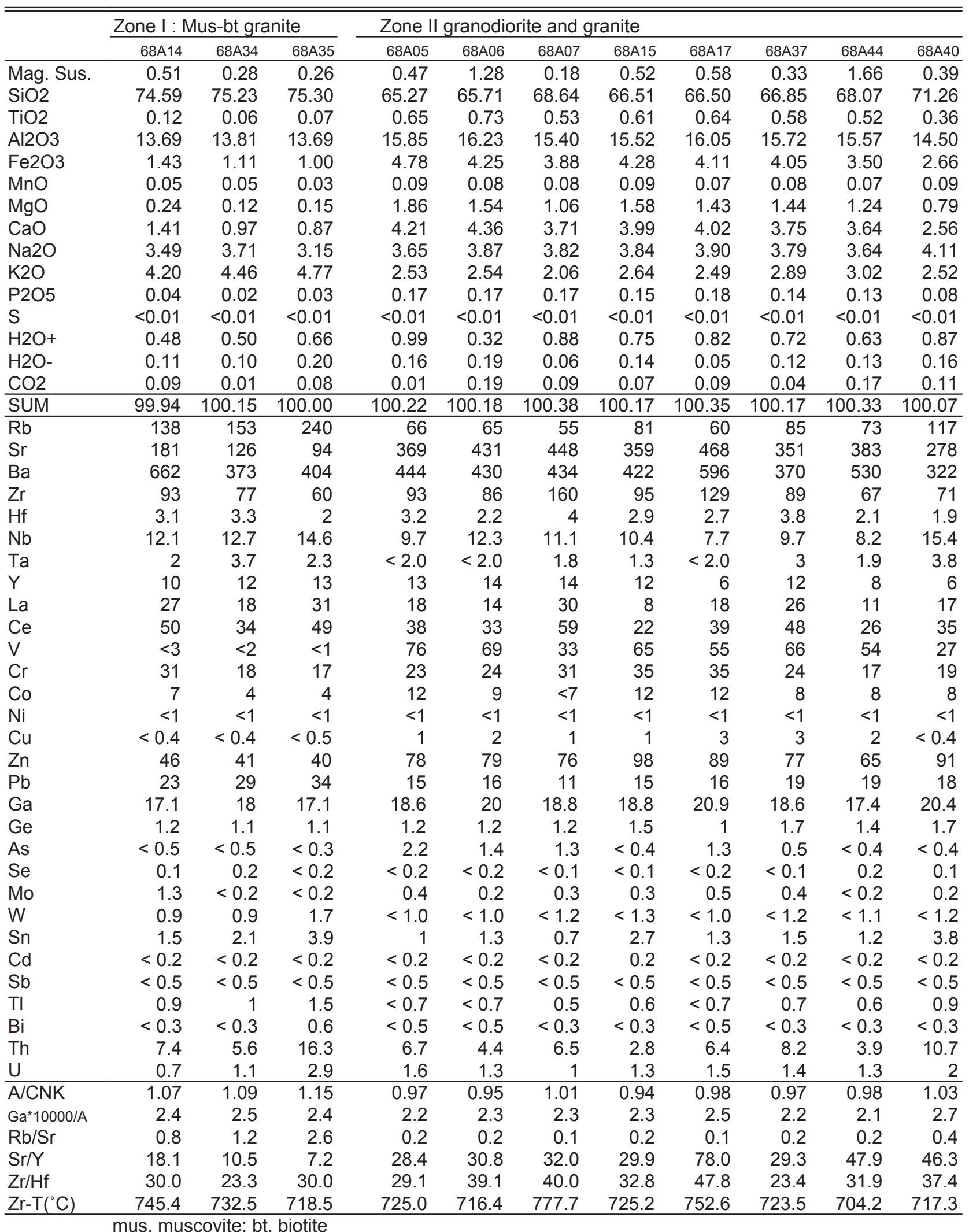


Appendix-1: Continued

\begin{tabular}{|c|c|c|c|c|c|c|c|c|c|c|c|}
\hline & \multicolumn{4}{|c|}{ Zone II granodiorite and granite } & \multicolumn{7}{|c|}{ Zone III granodiorite and granite } \\
\hline & $68 \mathrm{~A} 16$ & $68 \mathrm{~A} 45$ & 68A38 & $68 \mathrm{~A} 43$ & $68 \mathrm{~A} 08$ & 68A19 & $68 \mathrm{~A} 27$ & $68 \mathrm{~A} 25$ & $68 \mathrm{~A} 28$ & $68 \mathrm{~A} 20$ & 68 A33 \\
\hline Mag. Sus. & 0.37 & 0.37 & 0.36 & 0.36 & 0.67 & 0.67 & 0.69 & 15.3 & 0.41 & 0.49 & 0.77 \\
\hline $\mathrm{SiO} 2$ & 72.15 & 74.31 & 73.07 & 73.46 & 62.05 & 62.36 & 62.87 & 65.40 & 65.45 & 66.29 & 67.09 \\
\hline $\mathrm{TiO} 2$ & 0.28 & 0.14 & 0.19 & 0.17 & 0.69 & 0.84 & 0.74 & 0.60 & 0.57 & 0.56 & 0.44 \\
\hline $\mathrm{Al} 2 \mathrm{O} 3$ & 14.34 & 13.92 & 14.11 & 14.33 & 16.10 & 16.35 & 15.60 & 15.78 & 16.99 & 15.16 & 15.31 \\
\hline $\mathrm{Fe} 2 \mathrm{O} 3$ & 1.91 & 1.33 & 1.61 & 1.49 & 6.17 & 5.87 & 6.31 & 4.64 & 4.06 & 4.91 & 3.56 \\
\hline $\mathrm{MnO}$ & 0.04 & 0.05 & 0.05 & 0.04 & 0.11 & 0.10 & 0.12 & 0.09 & 0.07 & 0.10 & 0.08 \\
\hline $\mathrm{MgO}$ & 0.58 & 0.26 & 0.42 & 0.30 & 2.84 & 2.37 & 2.69 & 1.70 & 1.28 & 2.17 & 2.03 \\
\hline $\mathrm{CaO}$ & 1.99 & 1.49 & 1.78 & 1.61 & 5.74 & 5.23 & 5.06 & 4.33 & 4.53 & 4.54 & 3.78 \\
\hline $\mathrm{Na} 2 \mathrm{O}$ & 3.00 & 3.69 & 3.71 & 3.60 & 2.97 & 3.53 & 3.00 & 3.77 & 3.31 & 3.03 & 3.35 \\
\hline $\mathrm{K} 2 \mathrm{O}$ & 4.93 & 4.00 & 3.90 & 4.09 & 2.40 & 2.29 & 2.78 & 2.55 & 2.90 & 2.77 & 3.46 \\
\hline P2O5 & 0.07 & 0.04 & 0.06 & 0.07 & 0.14 & 0.21 & 0.17 & 0.17 & 0.12 & 0.12 & 0.13 \\
\hline S & $<0.01$ & $<0.01$ & $<0.01$ & $<0.01$ & 0.01 & $<0.01$ & 0.02 & $<0.01$ & $<0.01$ & $<0.01$ & $<0.01$ \\
\hline $\mathrm{H} 2 \mathrm{O}+$ & 0.45 & 0.63 & 0.76 & 0.66 & 0.80 & 0.87 & 0.74 & 0.88 & 0.72 & 0.74 & 0.64 \\
\hline H2O- & 0.20 & 0.08 & 0.26 & 0.10 & 0.13 & 0.11 & 0.25 & 0.16 & 0.37 & 0.07 & 0.29 \\
\hline CO2 & 0.02 & 0.01 & 0.05 & 0.03 & 0.16 & 0.19 & 0.01 & 0.15 & 0.01 & 0.01 & 0.18 \\
\hline SUM & 99.96 & 99.95 & 99.97 & 99.95 & 100.31 & 100.32 & 100.35 & 100.22 & 100.38 & 100.47 & 100.34 \\
\hline $\mathrm{Rb}$ & 92 & 124 & 122 & 119 & 72 & 57 & 93 & 69 & 92 & 95 & 93 \\
\hline $\mathrm{Sr}$ & 328 & 232 & 241 & 306 & 270 & 401 & 247 & 360 & 345 & 230 & 357 \\
\hline $\mathrm{Ba}$ & 726 & 509 & 547 & 600 & 363 & 459 & 426 & 439 & 481 & 318 & 488 \\
\hline $\mathrm{Zr}$ & 78 & 83 & 81 & 105 & 124 & 119 & 128 & 134 & 119 & 124 & 106 \\
\hline $\mathrm{Hf}$ & 1.5 & 3.7 & 2.1 & 3.1 & 3.6 & 3.2 & 3 & 3 & 3.9 & 4.2 & 3.3 \\
\hline $\mathrm{Nb}$ & 6.7 & 11.3 & 11 & 10 & 8.6 & 10.9 & 11.6 & 10.5 & 11 & 9.1 & 9 \\
\hline $\mathrm{Ta}$ & 1 & 1.4 & 2.4 & 1.9 & 2.6 & 2.4 & 2.6 & 2.6 & 3.1 & 3.9 & 1.4 \\
\hline$Y$ & 6 & 11 & 12 & 11 & 21 & 18 & 19 & 17 & 10 & 16 & 13 \\
\hline La & 16 & 20 & 20 & 21 & 16 & 37 & 8 & 23 & 20 & 37 & 21 \\
\hline $\mathrm{Ce}$ & 29 & 28 & 41 & 44 & 36 & 68 & 23 & 41 & 36 & 58 & 34 \\
\hline V & 21 & 4 & 12 & 3 & 122 & 113 & 119 & 79 & 31 & 90 & 69 \\
\hline $\mathrm{Cr}$ & 25 & 11 & 22 & 25 & 75 & 34 & 55 & 32 & 15 & 98 & 100 \\
\hline Co & 6 & $<4$ & 6 & $<4$ & 18 & 18 & 12 & 11 & 9 & 13 & 15 \\
\hline $\mathrm{Ni}$ & $<1$ & $<1$ & $<1$ & $<1$ & 5 & 6 & 6 & 1 & 1 & 6 & 13 \\
\hline $\mathrm{Cu}$ & $<0.3$ & 1 & 1 & $<0.4$ & 10 & 9 & 16 & 11 & $<0.5$ & 6 & 1 \\
\hline $\mathrm{Zn}$ & 47 & 47 & 48 & 50 & 67 & 81 & 74 & 71 & 56 & 60 & 40 \\
\hline $\mathrm{Pb}$ & 26 & 26 & 25 & 21 & 12 & 13 & 14 & 14 & 16 & 16 & 11 \\
\hline $\mathrm{Ga}$ & 15.8 & 18.3 & 18.7 & 17.1 & 16.3 & 18.6 & 16.2 & 18.2 & 17.5 & 14.6 & 14.3 \\
\hline $\mathrm{Ge}$ & 1 & 1.4 & 1.4 & 1.4 & 1.5 & 1.5 & 1.3 & 1.4 & 1.2 & 1.6 & 1.2 \\
\hline As & $<0.5$ & $<0.5$ & 0.9 & $<0.4$ & 0.7 & 0.7 & $<0.4$ & 2.2 & $<0.4$ & 0.6 & 0.7 \\
\hline $\mathrm{Se}$ & 0.2 & 0.2 & 0.2 & 0.2 & $<0.1$ & 0.1 & $<0.1$ & $<0.2$ & $<0.1$ & $<0.1$ & $<0.1$ \\
\hline Mo & 0.3 & $<0.2$ & $<0.2$ & $<0.2$ & 0.8 & 0.2 & 1.6 & 1 & 0.5 & 1.1 & 0.3 \\
\hline W & 0.7 & 0.9 & 0.7 & 1.4 & $<1.4$ & $<1.4$ & $<1.4$ & $<1.0$ & 1.7 & $<1.2$ & 0.5 \\
\hline Sn & 0.8 & 2.3 & 2 & 2 & 1.3 & 1.1 & 2 & 1.3 & 1.3 & 1.9 & 1.2 \\
\hline $\mathrm{Cd}$ & $<0.2$ & $<0.2$ & $0 . \overline{2}$ & $0 . \overline{2}$ & 0.2 & 0.2 & $<0.2$ & $<0.2$ & $<0.2$ & 0.3 & $<0.2$ \\
\hline $\mathrm{Sb}$ & $<0.5$ & $<0.5$ & $<0.5$ & 0.6 & $<0.5$ & $<0.5$ & $<0.5$ & $<0.5$ & $<0.5$ & $<0.5$ & $<0.5$ \\
\hline $\mathrm{TI}$ & 0.8 & 1.2 & 1.1 & 1.4 & 0.4 & 0.4 & 0.6 & $<0.7$ & 0.4 & 0.7 & 0.6 \\
\hline $\mathrm{Bi}$ & 0.3 & $<0.3$ & $<0.3$ & 0.3 & $<0.3$ & $<0.3$ & $<0.4$ & $<0.5$ & 1.9 & $<0.3$ & $<0.3$ \\
\hline Th & 5.9 & 5.2 & 8.3 & 4.9 & 6 & 9.8 & 4.8 & 9.2 & 9.7 & 15.8 & 10.3 \\
\hline U & 1 & 1.2 & 1.3 & $<0.5$ & 2.2 & 1 & 1.7 & 2.8 & 1.8 & 1.2 & 1.5 \\
\hline A/CNK & 1.03 & 1.06 & 1.04 & 1.08 & 0.90 & 0.92 & 0.91 & 0.94 & 1.01 & 0.93 & 0.95 \\
\hline $\mathrm{Ga}^{*} 10000 / \mathrm{A}$ & 2.1 & 2.5 & 2.5 & 2.3 & 1.9 & 2.2 & 2.0 & 2.2 & 1.9 & 1.8 & 1.8 \\
\hline $\mathrm{Rb} / \mathrm{Sr}$ & 0.3 & 0.5 & 0.5 & 0.4 & 0.3 & 0.1 & 0.4 & 0.2 & 0.3 & 0.4 & 0.3 \\
\hline $\mathrm{Sr} / \mathrm{Y}$ & 54.7 & 21.1 & 20.1 & 27.8 & 12.9 & 22.3 & 13.0 & 21.2 & 34.5 & 14.4 & 27.5 \\
\hline $\mathrm{Zr} / \mathrm{Hf}$ & 52.0 & 22.4 & 38.6 & 33.9 & 34.4 & 37.2 & 42.7 & 44.7 & 30.5 & 29.5 & 32.1 \\
\hline $\mathrm{Zr}-\mathrm{T}\left({ }^{\circ} \mathrm{C}\right)$ & 725.9 & 735.4 & 730.5 & 754.9 & 734.5 & 734.0 & 740.9 & 750.0 & 747.4 & 745.5 & 735.3 \\
\hline
\end{tabular}


Appendix-1: Continued

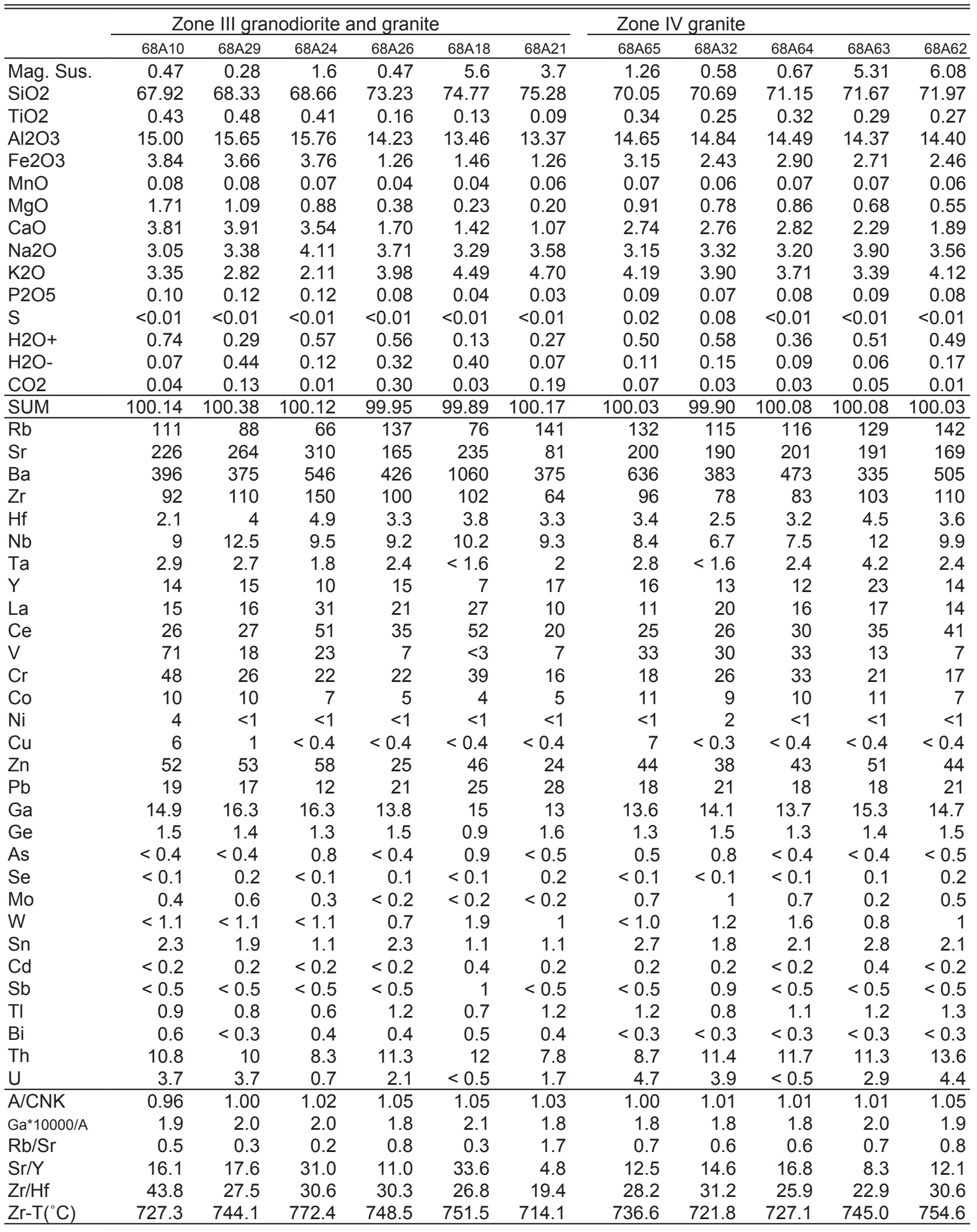


Appendix-1: Continued

\begin{tabular}{|c|c|c|c|c|c|c|c|c|c|c|c|}
\hline & \multicolumn{6}{|c|}{ Zone IV granite } & \multicolumn{5}{|c|}{ Zone V granodiorite } \\
\hline & $68 \mathrm{~A} 59$ & $68 \mathrm{~A} 49$ & $68 \mathrm{~A} 22$ & $68 \mathrm{~A} 47$ & $68 \mathrm{~A} 67$ & $68 \mathrm{~A} 48$ & 68A51 & 68A52 & $68 \mathrm{~A} 53$ & 68 A54 & $68 \mathrm{A55}$ \\
\hline Mag. Sus. & 3.81 & 7.01 & 2.71 & 4.81 & 1.28 & 2.85 & 10.7 & 9.91 & 11.1 & 0.76 & 9.31 \\
\hline $\mathrm{SiO} 2$ & 72.08 & 72.18 & 73.26 & 74.10 & 74.67 & 75.09 & 65.87 & 66.80 & 67.51 & 68.08 & 68.31 \\
\hline $\mathrm{TiO} 2$ & 0.25 & 0.27 & 0.16 & 0.13 & 0.08 & 0.10 & 0.54 & 0.44 & 0.49 & 0.46 & 0.43 \\
\hline $\mathrm{Al} 2 \mathrm{O} 3$ & 14.67 & 14.54 & 14.06 & 13.70 & 13.67 & 13.34 & 15.84 & 15.89 & 15.58 & 15.67 & 15.62 \\
\hline $\mathrm{Fe} 2 \mathrm{O} 3$ & 2.47 & 2.43 & 1.93 & 1.88 & 1.33 & 1.33 & 4.74 & 3.86 & 4.01 & 3.61 & 3.47 \\
\hline $\mathrm{MnO}$ & 0.06 & 0.06 & 0.04 & 0.05 & 0.04 & 0.05 & 0.09 & 0.08 & 0.08 & 0.08 & 0.07 \\
\hline $\mathrm{MgO}$ & 0.53 & 0.58 & 0.28 & 0.23 & 0.15 & 0.19 & 1.74 & 1.41 & 1.43 & 1.24 & 1.25 \\
\hline $\mathrm{CaO}$ & 2.47 & 2.23 & 1.78 & 1.13 & 0.84 & 1.20 & 4.43 & 4.16 & 3.57 & 3.89 & 3.60 \\
\hline $\mathrm{Na} 2 \mathrm{O}$ & 3.84 & 3.85 & 4.04 & 3.77 & 4.21 & 3.51 & 3.57 & 3.75 & 3.66 & 3.85 & 3.81 \\
\hline $\mathrm{K} 2 \mathrm{O}$ & 3.31 & 3.57 & 3.54 & 4.49 & 4.54 & 4.50 & 2.47 & 2.55 & 2.75 & 2.40 & 2.59 \\
\hline P2O5 & 0.07 & 0.09 & 0.06 & 0.04 & 0.03 & 0.04 & 0.14 & 0.10 & 0.13 & 0.11 & 0.11 \\
\hline$S$ & $<0.01$ & $<0.01$ & $<0.01$ & $<0.01$ & $<0.01$ & $<0.01$ & $<0.01$ & $<0.01$ & $<0.01$ & $<0.01$ & $<0.01$ \\
\hline $\mathrm{H} 2 \mathrm{O}+$ & 0.40 & 0.17 & 0.36 & 0.35 & 0.29 & 0.49 & 0.65 & 0.58 & 0.91 & 0.45 & 0.84 \\
\hline H2O- & 0.05 & 0.07 & 0.34 & 0.05 & 0.07 & 0.12 & 0.18 & 0.34 & 0.24 & 0.29 & 0.15 \\
\hline CO2 & 0.05 & 0.01 & 0.03 & 0.01 & 0.03 & 0.01 & 0.01 & 0.43 & 0.01 & 0.01 & 0.11 \\
\hline SUM & 100.25 & 100.05 & 99.88 & 99.93 & 99.95 & 99.97 & 100.25 & 100.39 & 100.37 & 100.14 & 100.36 \\
\hline $\mathrm{Rb}$ & 113 & 130 & 98 & 127 & 159 & 174 & 83 & 81 & 83 & 72 & 78 \\
\hline $\mathrm{Sr}$ & 190 & 186 & 195 & 106 & 69 & 97 & 293 & 278 & 294 & 322 & 306 \\
\hline $\mathrm{Ba}$ & 520 & 341 & 1480 & 851 & 385 & 304 & 446 & 422 & 481 & 417 & 447 \\
\hline $\mathrm{Zr}$ & 113 & 93 & 117 & 99 & 73 & 80 & 101 & 93 & 110 & 95 & 112 \\
\hline $\mathrm{Hf}$ & 3.7 & 3 & 4 & 4 & 3.7 & 4.3 & 2.6 & 2.2 & 2.7 & 2.4 & 2.9 \\
\hline $\mathrm{Nb}$ & 8.8 & 10.4 & 7.6 & 10.9 & 12.1 & 10.9 & 7.8 & 7.4 & 8.3 & 7.8 & 7.5 \\
\hline $\mathrm{Ta}$ & 2 & 2.8 & 2.1 & 3.2 & 3.1 & 3 & $<1.9$ & 1.6 & 1.6 & 2 & 2.1 \\
\hline$Y$ & 17 & 20 & 14 & 20 & 23 & 17 & 15 & 15 & 13 & 11 & 12 \\
\hline La & 24 & 19 & 34 & 23 & 16 & 16 & 18 & 19 & 19 & 12 & 24 \\
\hline $\mathrm{Ce}$ & 43 & 38 & 58 & 43 & 36 & 28 & 34 & 30 & 33 & 26 & 43 \\
\hline V & 10 & 17 & $<3$ & 4 & 2 & 5 & 81 & 53 & 59 & 49 & 43 \\
\hline $\mathrm{Cr}$ & 32 & 27 & 42 & 54 & 19 & 18 & 15 & 34 & 33 & 20 & 31 \\
\hline Co & 9 & 7 & 8 & 7 & $<4$ & 4 & 13 & 10 & 11 & 12 & 9 \\
\hline $\mathrm{Ni}$ & $<1$ & $<1$ & $<1$ & $<1$ & $<1$ & $<1$ & 1 & 1 & 1 & 1 & 1 \\
\hline $\mathrm{Cu}$ & $<0.4$ & $<0.4$ & $<0.4$ & $<0.4$ & $<0.4$ & $<0.4$ & 1 & $<0.4$ & 5 & 1 & 1 \\
\hline $\mathrm{Zn}$ & 45 & 43 & 37 & 36 & 16 & 24 & 57 & 49 & 59 & 57 & 47 \\
\hline $\mathrm{Pb}$ & 18 & 19 & 19 & 22 & 27 & 34 & 9 & 11 & 13 & 29 & 11 \\
\hline $\mathrm{Ga}$ & 15.3 & 15.6 & 14.2 & 14.4 & 15.3 & 14.3 & 16.5 & 16.7 & 16 & 16.4 & 15.8 \\
\hline $\mathrm{Ge}$ & 1.4 & 1.6 & 1.3 & 1.2 & 1.4 & 1.5 & 1.4 & 1.1 & 1.4 & 1.4 & 1.5 \\
\hline As & $<0.4$ & 0.3 & $<0.4$ & $<0.5$ & $<0.5$ & $<0.6$ & 0.4 & $<0.4$ & $<0.4$ & 0.4 & 0.4 \\
\hline $\mathrm{Se}$ & $<0.1$ & $<0.1$ & 0.2 & 0.2 & $<0.1$ & $<0.1$ & $<0.1$ & 0.2 & 0.1 & $<0.1$ & 0.1 \\
\hline Mo & 0.4 & 0.2 & $<0.2$ & $<0.2$ & 0.4 & $<0.2$ & 0.7 & 1.3 & 2 & 0.3 & 1.2 \\
\hline W & 1.5 & 2 & 0.7 & 0.8 & 2 & 2 & $<1.1$ & 0.8 & $<1.1$ & $<1.1$ & $<1.0$ \\
\hline Sn & 2.2 & 2.1 & 1.7 & 2.3 & 1.6 & 1.8 & 1.3 & 1.6 & 1.3 & 1.3 & 1 \\
\hline $\mathrm{Cd}$ & $<0.2$ & $<0.2$ & $<0.2$ & 0.4 & $<0.2$ & $<0.2$ & $<0.2$ & 0.3 & $<0.2$ & 0.3 & $<0.2$ \\
\hline $\mathrm{Sb}$ & $<0.5$ & $<0.5$ & $<0.5$ & $<0.5$ & $<0.5$ & $<0.5$ & $<0.5$ & 0.5 & $<0.5$ & $<0.5$ & $<0.5$ \\
\hline $\mathrm{TI}$ & 1.1 & 1.2 & 1.1 & 1.2 & 1.3 & 1.5 & 0.5 & 0.4 & 0.5 & 0.6 & 0.8 \\
\hline $\mathrm{Bi}$ & $<0.3$ & 0.4 & 0.5 & 0.3 & 0.3 & $<0.3$ & $<0.3$ & $<0.3$ & $<0.3$ & 0.5 & 0.3 \\
\hline Th & 14.3 & 12.5 & 11.2 & 12.6 & 13.3 & 21.6 & 7 & 8.5 & 6.8 & 5.6 & 8.3 \\
\hline U & 3.6 & $<0.5$ & 1.5 & $<0.5$ & 2.1 & 5.7 & 2.3 & 2.1 & 1.4 & 1.2 & 2 \\
\hline A/CNK & 1.02 & 1.02 & 1.03 & 1.04 & 1.02 & 1.04 & 0.95 & 0.96 & 1.01 & 0.98 & 1.00 \\
\hline $\mathrm{Ga}^{*} 10000 / \mathrm{A}$ & 2.0 & 2.0 & 1.9 & 2.0 & 2.1 & 2.0 & 2.0 & 2.0 & 1.9 & 2.0 & 1.9 \\
\hline $\mathrm{Rb} / \mathrm{Sr}$ & 0.6 & 0.7 & 0.5 & 1.2 & 2.3 & 1.8 & 0.3 & 0.3 & 0.3 & 0.2 & 0.3 \\
\hline $\mathrm{Sr} / \mathrm{Y}$ & 11.2 & 9.3 & 13.9 & 5.3 & 3.0 & 5.7 & 19.5 & 18.5 & 22.6 & 29.3 & 25.5 \\
\hline $\mathrm{Zr} / \mathrm{Hf}$ & 30.5 & 31.0 & 29.3 & 24.8 & 19.7 & 18.6 & 38.8 & 42.3 & 40.7 & 39.6 & 38.6 \\
\hline $\mathrm{Zr}-\mathrm{T}\left({ }^{\circ} \mathrm{C}\right)$ & 753.2 & 738.0 & 758.6 & 748.1 & 722.1 & 731.8 & 730.1 & 725.4 & 745.1 & 730.3 & 746.2 \\
\hline
\end{tabular}


Appendix-1: Continued

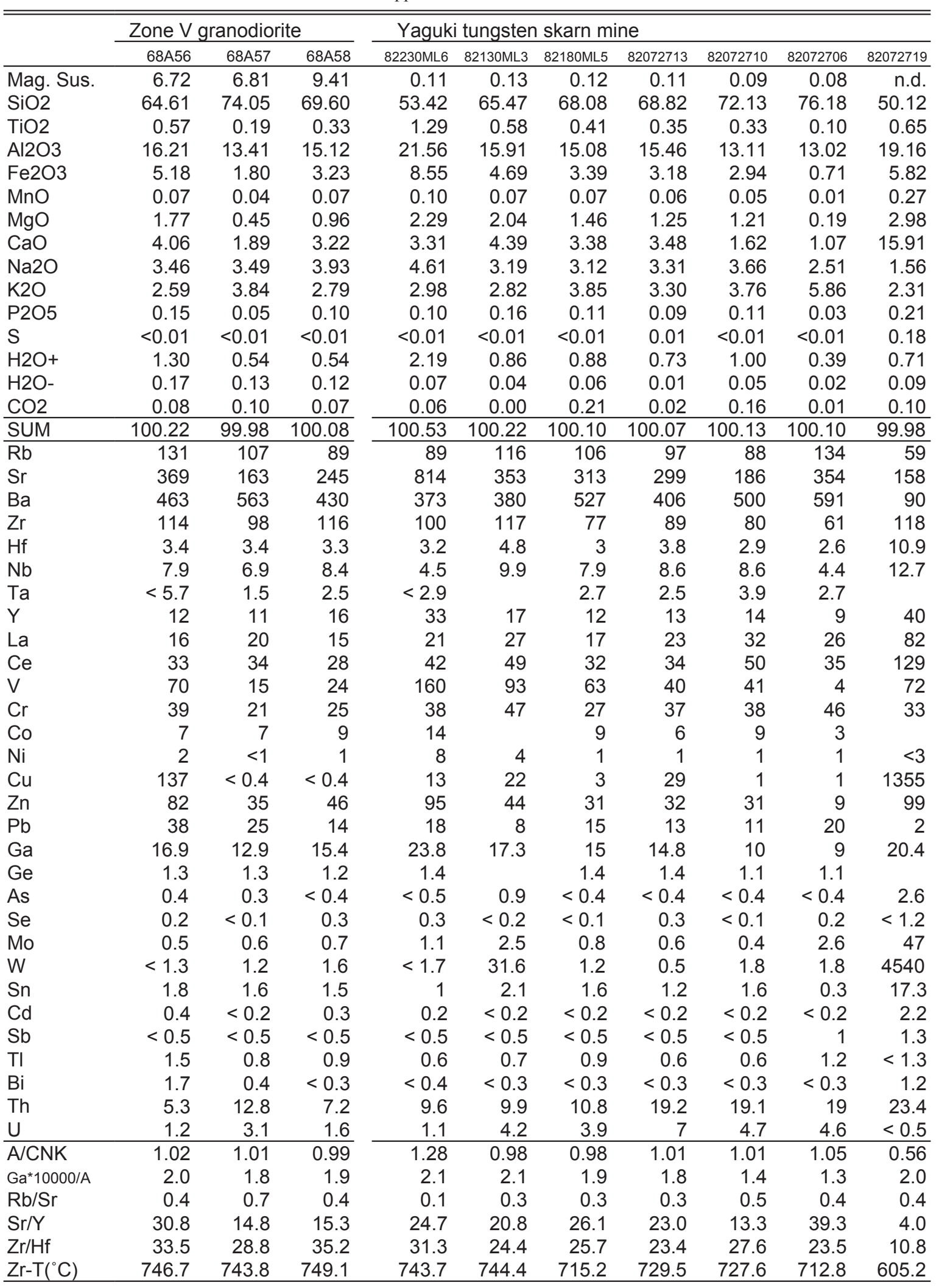

Sample localities of the analyzed granitoids from the Yaguki mine.

82230ML6: 230 ML (meter level), No. 3 Orebody, Kotobuki No. 1 Exploration drift. Diorite.

82130ML3: 130 ML, W320 Cross Cut. Granodiorite.

82180ML5: 180ML, Exploration drift to north. Granodiorite.

82072713: 230 ML. Freshest granodiorite.

82072710: 230 ML. Fine granodiorite. Pink K-feldspar along joint.

82072706: $80 \mathrm{ML}$, W600. Fine-graine dikelet in slate.

82072719: Akahage Orebody. Scheelite disseminated altered granodiorite. 